\title{
Origin, age, and significance of deep-seated granulite-facies migmatites in the Barrow zones of Scotland, Cairn Leuchan, Glen Muick area
}

Richard M. Palin ${ }^{1,2 *}$, Abdul B. Sayed ${ }^{1}$, Richard W. White ${ }^{1,3}$, and Regina Mertz-Kraus ${ }^{1}$

${ }^{1}$ Institute of Geosciences, Johannes-Gutenberg University of Mainz, 55128 Mainz, Germany

${ }^{2}$ Department of Geology and Geological Engineering, Colorado School of Mines, Golden, CO 80401, USA

${ }^{3}$ School of Earth and Environmental Sciences, The University of St Andrews, St Andrews, KY16 9AL, United Kingdom

*Corresponding author: richardmpalin@gmail.com

Short title: Granulite-facies Barrovian metamorphism

\section{ABSTRACT}

Petrological modelling of granulite-facies mafic and semipelitic migmatites from Cairn Leuchan, northeast Scotland, has provided new constraints on the pressure $(P)$ and temperature $(T)$ conditions of high-grade metamorphism in the type-locality Barrow zones. Phase diagrams constructed in the

$\mathrm{Na}_{2} \mathrm{O}-\mathrm{CaO}-\mathrm{K}_{2} \mathrm{O}-\mathrm{FeO}-\mathrm{MgO}-\mathrm{Al}_{2} \mathrm{O}_{3}-\mathrm{SiO}_{2}-\mathrm{H}_{2} \mathrm{O}-\mathrm{TiO}_{2}-\mathrm{O}_{2}$ system have constrained the $P-T$ conditions of peak metamorphism in the Glen Muick region of the upper-sillimanite zone (Sill+Kfs) to have been at least $\sim 840{ }^{\circ} \mathrm{C}$ at $\sim 9$ kbar (high-pressure granulite facies). These conditions are approximately $\sim 120^{\circ} \mathrm{C}$ and $\sim 3$ kbar higher than those recorded by lower-sillimanite zone (Sill+Ms) units located only a few kilometres away to the southeast at Glen Girnock, indicating the presence of a significant thermal and barometric high exposed within the Scottish Dalradian and supporting previous suppositions of a potential tectonic break between the two regions. U-Pb zircon geochronology performed on these mafic migmatites produced ages of c. 540-470 Ma from grains with both igneous and metamorphic morphological characteristics. Their basaltic protoliths likely formed during a period of volcanism dated at $\sim 570 \mathrm{Ma}$, associated with passive-margin extension prior to the onset of Iapetus Ocean closure, and high-grade metamorphism and partial melting is interpreted to have taken place at around $470 \mathrm{Ma}$, synchronous with sillimanite-grade metamorphism recorded elsewhere in the Dalradian. These high-grade Cairn Leuchan lithologies are interpreted as representing a fragment of Grampian Terrane lower crust that

This article has been accepted for publication and undergone full peer review but has not been through the copyediting, typesetting, pagination and proofreading process, which may lead to differences between this version and the Version of Record. Please cite this article as doi: $10.1111 /$ jmg. 12428

This article is protected by copyright. All rights reserved. 
was exhumed via displacement along a steeply dipping tectonic discontinuity related to the Portsoy-Duchray Hill Lineament, and are not pre-Caledonian Mesoproterozoic basement, as suggested by some previous studies. Veins within some mafic migmatites in the Cairn Leuchan area, composed almost entirely (>80\%) of garnet, with minor quartz, plagioclase, amphibole, and clinopyroxene, are interconnected with leucosomes and are interpreted to represent former garnet-bearing melt segregations that have been locally drained of almost all melt. Thus, mafic components of the lower crust, currently underlying relatively lower-grade metasediments exposed to the southeast, may represent a potential source rock for widely documented, post-orogenic felsic plutons, sills, and dykes that occur throughout the Grampian Terrane.

Keywords: Grampian Terrane; Barrow zones; granulite; metabasalt; THERMOCALC

\section{INTRODUCTION}

The seminal works of Barrow $(1893,1912)$ conducted on the geology of the Scottish Highlands showed that pelitic rocks undergoing regional metamorphism exhibit systematic changes in mineral assemblage, primarily as a function of metamorphic grade. Since this discovery, Barrovian-style metamorphism - identified in metapelites via the progressive appearance of the index minerals chlorite, biotite, garnet, staurolite, kyanite, and sillimanite - has been documented in almost all major mountain belts worldwide (e.g. Brown \& Walker, 1993; Fraser, Searle, Parrish, \& Noble, 2001; Goscombe \& Hand, 2000; Maruyama, Liou, \& Zhang, 1994; Okay, 1989; Smye, Holland, Parrish, \& Condon, 2011; Weller et al., 2013; Wing \& Ferry, 2002). However, despite focused study, key questions remain concerning the tectonothermal history of metamorphic rocks from this Scottish type locality, including the timing and duration of burial and deformation, and the highest pressure $(P)$ and temperature $(T)$ conditions reached within the sequence (e.g. Aoki, Windley, Maruyama, \& Omori, 2014a, 2014b; Atherton, 1977; Baker, 1985; Baker \& Droop, 1983; Chinner, 1960, 1966; Harte \& Johnson, 1969; Tilley, 1925; Viete, Oliver, \& Wilde, 2014; Vorhies, Ague, \& Schmitt, 2013, and many others).

Many previous investigations into the metamorphic evolution of these Barrow zone units have employed cation exchange-based conventional thermobarometry to determine $P-T$ conditions of equilibration (e.g. Baker, 1985), although at high grade conditions, such an approach is limited by diffusional re-equilibration of mineral compositions during retrograde cooling (Frost \& Chacko, 1989; Kohn \& Spear, 2000). Quantitative phase equilibrium modelling represents an alternative methodology with which to interpret the thermal history of metamorphic rocks, as it relies primarily on the preserved assemblage

This article is protected by copyright. All rights reserved. 
rather than mineral compositions (Powell \& Holland, 2008), and allows sections of $P-T$ paths to be deduced from observed or interpreted changes in mineral proportions (e.g. Stüwe \& Powell, 1995; White, Powell, \& Clarke, 2002). The formulation and expansion of internally consistent thermodynamic datasets containing phases relevant to petrological investigations (e.g. Berman, 1988; Holland \& Powell, 1998, 2011), and recent development of activity-composition $(a-x)$ relations for minerals and melt in suprasolidus metapelitic (White, Powell, Holland, Johnson, \& Green, 2014a; White, Powell, \& Johnson, 2014b) and metabasic (Green et al., 2016) lithologies, now allows the tectonothermal evolution of the highest-grade rocks from the type-locality Barrow zone units to be re-examined using these techniques.

The hill of Cairn Leuchan, located $5 \mathrm{~km}$ south-east of Ballater in Glen Muick, Upper Deeside, lies at the far northeastern end of the Barrow zone sequence within the Grampian Terrane (Fig. 1). The mineral zones identified by Barrow $(1893,1912)$ outline a general increase in metamorphic grade towards this northeastern corner, and the granulite-facies mineral assemblages and evidence for partial melting visible in both metasedimentary and metabasic lithologies at Cairn Leuchan are consistent with these outcrops preserving the highest $P-T$ conditions throughout the entire region (Baker \& Droop, 1983). However, a number of recent studies have debated whether these unusually high-grade lithologies formed during the Ordovician, synchronously with the rest of the Barrow zone sequence (Aoki et al., 2014a, 2014b), or whether these high-grade migmatites represent fragments of pre-orogenic, Mesoproterozoic lower crust that have been physically juxtaposed against geologically unrelated upper amphibolite-facies Barrovian units via later fault activity (Viete et al., 2014). In this work, new petrological observations, rock and mineral chemical analyses, phase diagram-based thermobarometry, and $\mathrm{U}-\mathrm{Pb}$ zircon ages are presented for granulite-facies mafic and semipelitic migmatites collected from the Cairn Leuchan region. Together, these data allow the origin, age, and $P-T$ conditions of metamorphism of these lithologies to be directly determined, and so provides allows discrimination between these competing interpretations for the tectonothermal evolution of the region.

\section{GEOLOGICAL BACKGROUND AND FIELD RELATIONS}

\subsection{The mid-Ordovician Grampian Event}

The Caledonian Orogeny formed in response to closure of the Iapetus Ocean, which initiated in the Cambrian (c. 500 Ma; Stephenson, Mendum, Fettes, \& Leslie, 2013a) and terminated upon the collision of Baltica-Avalonia and Laurentia in the Silurian (c. 395 Ma; Oliver, 2001; Soper, Strachan, Holdsworth, Gayer, \& O'Greiling, 1992). The earliest 
collisional episode in this orogeny was the mid-Ordovician Grampian Event, which resulted from the accretion of an island arc system (the Midland Valley Terrane) to the southeastern edge of the Laurentian continental margin (the Grampian Terrane) (Fig. 1; Dewey \& Mange, 1999; McKerrow, Mac Niocaill, \& Dewey, 2000; Soper, Ryan, \& Dewey, 1999). The pelitic-to-psammitic sedimentary protoliths of the classical Barrow zone metamorphic sequence (the Dalradian Supergroup) formed on this Laurentian passive margin prior to ocean closure (Dewey, 1969; Harris \& Pitcher, 1975; Tanner et al., 2013). The beginning of arc-continent collision was recorded by ophiolite obduction onto the Laurentian margin at $490 \pm 4 \mathrm{Ma}$ (K-Ar hornblende; Chew et al., 2010), with a U-Pb-corrected Ar-Ar white mica age of c. $488 \mathrm{Ma}$ obtained from deformed biotite-grade metasedimentary units (Viete, Hermann, Lister, \& Stenhouse, 2011; Viete, Oliver, Fraser, Forster, \& Lister, 2013) likely marking the onset of crustal thickening and initiation of Barrovian metamorphism.

Garnet-whole-rock Sm-Nd data reported by Oliver, Chen, Buchwaldt, and Hegner (2000) and Baxter, Ague, and De Paolo (2002) from Dalradian metapelites record prograde garnet growth initiating at c. 473-467 Ma and continuing until $464.8 \pm 2.7 \mathrm{Ma}$ in upper-sillimanite zone units. This c. 465 Ma age was interpreted by Baxter et al. (2002) to date the timing of peak sillimanite-grade metamorphism in the region. Syn-orogenic granitic and gabbroic intrusions throughout the Grampian Terrane are variably deformed, and have emplacement ages of c. 473-465 Ma (U-Pb zircon and monazite, $\mathrm{Rb}-\mathrm{Sr}$ whole-rock; Appleby et al., 2010; Dempster et al., 2002; Kneller \& Aftalion, 1987; Oliver et al., 2000; Oliver, Wilde, \& Wang, 2008) and c. 475-470 Ma (U-Pb zircon; Carty, Connelley, Hudson, \& Gale, 2012; Dempster et al., 2002; Oliver et al., 2008), respectively. Post-peak exhumation and cooling of the Barrow zone metasediments through the $\sim 500{ }^{\circ} \mathrm{C}$ isotherm had occurred by c. $460 \mathrm{Ma}$ (Rb-Sr, Ar-Ar, and $\mathrm{K}-\mathrm{Ar}$ muscovite and biotite; Dempster, Hudson, \& Rogers, 1995; Oliver et al., 2000; Soper et al., 1999; Viete et al., 2013), suggesting that the entire Grampian Event (arc-continent collision) lasted only $\sim 25$ Myr; a relatively short time in comparison with the typical duration of larger-scale continent-continent collision (at least 50 Myr; Dewey, 2005; St-Onge, Searle, \& Wodicka, 2006).

Estimated peak $P-T$ conditions achieved within each of the Barrow zones increase both in a northern direction away from the Highland Boundary Fault - the southern tectonic boundary of the Grampian Terrane - and in a northeasterly direction towards the low-pressure/high-temperature Buchan Zones, north of Aberdeen (Fig. 1). No reliable thermobarometric estimates exist for low-grade chlorite and biotite zones due to the absence of useful pressure- or temperature-sensitive mineral assemblages in their rocks; however, peak $P-T$ conditions of $\sim 5.0-6.5 \mathrm{kbar}$ and $\sim 500-550{ }^{\circ} \mathrm{C}, \sim 6.5 \mathrm{kbar}$ and $\sim 585-615{ }^{\circ} \mathrm{C}$, and $\sim 6.5-8.0 \mathrm{kbar}$ and $\sim 550-640{ }^{\circ} \mathrm{C}$ have been reported for the garnet, 
staurolite, and kyanite zones, respectively (Baker, 1985; Dempster, 1985; McLellan, 1985; Vorhies \& Ague, 2011). Lower sillimanite-zone muscovite-bearing pelites reportedly reached maximum $P-T$ conditions of $\sim 4.5-7.5$ kbar and $\sim 610-690{ }^{\circ} \mathrm{C}$ (Ague, Baxter, \& Eckert Jr, 2001; Baker, 1985; Dempster, 1985; Vorhies \& Ague, 2011), with these data interpreted to record a clockwise $P-T$ evolution with a late-stage, short-lived, and high-temperature excursion during decompression associated with the nearby emplacement of syn-orogenic granitic and gabbroic magmas (see above; Baxter et al., 2002; Vorhies \& Ague, 2011).

Upper sillimanite-zone pelites, which contain K-feldspar and lack prograde muscovite, occur in and around the Glen Muick region (Fig. 1) of Upper Deeside, and are thought to record the most extreme $P-T$ conditions reached within the Grampian Terrane (Baker, 1985; Baker \& Droop, 1983). Abundant garnet-hornblende-clinopyroxene mafic gneisses also outcrop on the hill of Cairn Leuchan (Figs 1 and 2) and are extensively migmatised. Although initially interpreted as Precambrian basement (Ramsay \& Sturt, 1979; Read, 1955; Smith, Goodman, \& Robertson, 2002; Sturt, Ramsay, Pingle, \& Teggin, 1977; Viete, Richards, Lister, Oliver, \& Banks, 2010), these mafic gneisses and intercalated metapsammite, metapelite, and calc-silicate lithologies have recently been stratigraphically re-assigned to the Crinan Subgroup of the Upper Dalradian Series (Stephenson et al., 2013b), and thus are considered contiguous with the rest of the lower-grade Barrow zone sequence. Detailed structural investigation has shown that these metamorphosed basic sheets were intruded as dykes and sills before regional-scale Grampian deformation, although some fine-grained rocks exposed near the base of the Subgroup are regarded as metavolcanic (Fettes, MacDonald, Fitton, Stephenson, \& Cooper, 2011; Stephenson et al., 2013b). High-resolution U-Pb spot secondary ion mass spectrometry dating of zircons from Glen Muick metapelites performed by Vorhies et al. (2013) showed that peak metamorphism occurred at c. $468 \pm 7 \mathrm{Ma}(\mathrm{MSWD}=0.9)$, matching that reported from elsewhere in the Grampian Terrane (e.g. Baxter et al., 2002; Breeding, Ague, Grove, \& Rupke, 2004; Viete et al., 2013), providing further evidence for their contemporaneous evolution. However, prior to this study, no geochronology has been performed on these granulite-facies metamafic members.

\subsection{Previous investigation of Glen Muick lithologies}

Conventional thermobarometry performed on Glen Muick metapelites (Vorhies \& Ague, 2011) and metabasites (Baker, 1985; Baker \& Droop, 1983) has produced peak $P-T$ conditions of $\sim 8-9 \mathrm{kbar}$ and $\sim 800-820^{\circ} \mathrm{C}$, which are notably higher from those recorded by lower-sillimanite-zone units $\left(\sim 4.5-7.5\right.$ kbar and $\left.\sim 610-690{ }^{\circ} \mathrm{C}\right)$, though these still may represent minima based on the likelihood of retrograde diffusion-driven change in mineral 
compositions during post-peak exhumation and cooling (Frost \& Chacko, 1989; Kohn \& Spear, 2000). This anomalous 'thermal high' in the Glen Muick region has been variably attributed to a syn- or post-metamorphic structural break that uplifted deeper-seated lower-crustal units (Baker, 1985), and/or syn-peak magma intrusion while the rocks were still deeply buried, thus producing a contact metamorphic imprint on regional-scale metamorphism (Viete et al., 2013; Vorhies \& Ague, 2011). Aoki et al. (2014a) recently performed phase equilibrium modelling of these Cairn Leuchan mafic migmatites in the $\mathrm{MnO}-\mathrm{Na}_{2} \mathrm{O}-\mathrm{CaO}-\mathrm{FeO}-\mathrm{MgO}-\mathrm{Al}_{2} \mathrm{O}_{3}-\mathrm{SiO}_{2}-\mathrm{H}_{2} \mathrm{O}$ system and suggested that these units had experienced high-pressure granulite-facies peak metamorphism at $\sim 12-14 \mathrm{kbar}$ (at $\sim 770-800{ }^{\circ} \mathrm{C}$ ), followed by amphibolite-facies retrograde equilibration at $\sim 5-8 \mathrm{kbar}$ and $\sim 580-700{ }^{\circ} \mathrm{C}$. They interpreted these $P-T$ data to show that high-grade Grampian Terrane Barrovian metamorphism was in fact a retrograde feature imprinted onto rocks that had previously experienced sequential subduction-related blueschist-, eclogite-, and high-pressure granulite-facies metamorphism during arc-continent collision. Notably, Aoki et al. (2014a) did not perform geochronological analysis of these mafic migmatites, and assumed an Ordovician age for metamorphism based on the age of retrogressed eclogites (c. $485 \mathrm{Ma}$ ) exposed $\sim 100 \mathrm{~km}$ to the north in Tomatin (Fig. 1a), although this interpretation has since been disputed Viete et al. (2014).

The Cairn Leuchan area (Fig. 1) exposes metre-scale to decametre-scale isolated outcrops of mafic migmatite (Fig. 2a), with some semipelitic gneiss also present (Fig. 2b). The mafic migmatites primarily contain garnet-hornblende-clinopyroxene-plagioclase matrix assemblages hosting numerous centimetre-scale leucosomes that range from isolated stroma to complex interconnected networks. The proportion of the main matrix phases varies considerably across the region, with hornblende in particular comprising between $\sim 30 \%$ and $\sim 70 \%$ volume of any individual sample. Small-scale quartz-plagioclase leucosomes commonly have diffuse boundaries with the host and may contain porphyroblasts of clinopyroxene and/or garnet, consistent with in situ partial melting (Fig. 2c). The larger, more distinct leucosomes range from being composed entirely of quartz and plagioclase to additionally containing combinations of clinopyroxene, hornblende, and/or garnet in variable proportions. Local concentrations of clinopyroxene (Fig. 2d) and garnet (Fig. 2c) commonly occur. The exceptionally garnet-rich bands, subsequently referred to as 'garnetite', are laterally discontinuous, with some examples showing abrupt transitions into garnet-absent leucosome at the millimetre-scale (Fig. 2e). Where such lateral connectivity occurred, the garnetite veins were invariably thinner than the garnet-absent segregations. Outcrop-scale evidence of localised melt mobility is provided by disrupted matrix folia associated with boudinage (Fig. 2f), although the small scale of the outcrops themselves did not allow for an in-depth assessment of large-scale melt 
transfer networks formed during migmatisation.

In this work, one semipelitic migmatite (CL01) and three mafic migmatites (CL02, CL03, and CL10) have been examined in order to constrain the age of metamorphism and tectonothermal evolution of the Cairn Leuchan/Glen Muick region of the Grampian Terrane. Individual outcrop localities and the distribution of different rock types are shown on Fig. 2. Phase abbreviations follow the guidelines of Kretz (1983), alongside L for silicate melt.

\section{PETROGRAPHY AND MINERAL CHEMISTRY}

Mineral compositional data were obtained on a JEOL JXA-8200 electron microprobe housed at the Institute of Geosciences, Johannes-Gutenberg University of Mainz, Germany. Operating conditions included an acceleration voltage of $15 \mathrm{kV}$, a beam current of $12 \mathrm{nA}$, and a spot size of $2 \mu \mathrm{m}$. A ZAF matrix correction for atomic number, absorption, and fluorescence was automatically applied to all analyses, and calibration was performed against a range of natural and synthetic standards. Multiple spot analyses and line profiles were taken across all major minerals in each sample to determine the extent of inter- and intra-crystalline compositional variation according to microstructural position. For the data presented below, mineral compositions were recalculated to standard numbers of oxygen per formula unit (pfu), with $\mathrm{H}_{2} \mathrm{O}$ assumed to be present in stoichiometric amounts. Where relevant, the proportion of ferric iron was estimated using the software AX (Holland, 2009). Representative mineral compositions from each sample are given in Table 1. Bulk-rock compositional data were obtained via X-ray fluorescence (XRF) using a Philips MagiXPRO spectrometer with a rhenium X-ray tube, also housed at the Institute of Geosciences, Johannes-Gutenberg University of Mainz, Germany, with titration used to determine individual amounts of $\mathrm{Fe}_{2} \mathrm{O}_{3}$ and $\mathrm{FeO}$. Whole-rock composition data are given in Table 2 .

Sample CL01 is heterogeneous semipelitic migmatite that contains centimetre-scale quartz- and feldspar-rich stromatic leucosome segregations within a quartz-, plagioclase-, biotite-, garnet-bearing matrix (Fig. 3a). At the outcrop scale, leucosome was observed to comprise approximately $20 \%$ volume of the rock as a whole (Fig. 2b). Rare sillimanite $(<1 \%)$, and accessory apatite $(<0.5 \%)$ and ilmenite $(<0.5 \%)$ also occur. A well-defined foliation within the matrix is defined by a common orientation of biotite laths and the elongation of quartz lenses (Fig. 3a). Garnet porphyroblasts are restricted to biotite-bearing matrix domains and are typically $\sim 0.2-0.5 \mathrm{~cm}$ in diameter. They commonly contain quartz and biotite inclusions, and have weak compositional zoning from core (relatively Ca-rich) to rim (relatively Fe-rich), having a compositional range of 
$\mathrm{Alm}_{55-60} \operatorname{Prp}_{17-19} \mathrm{Grs}_{18-24} \mathrm{Sps}_{3-4}$ (Fig. 4a). Very thin outer rims $<50 \mu \mathrm{m}$ in width show elevated spessartine contents (up to $6 \%$ ), which are likely related to retrograde cation exchange with matrix phases (Kohn \& Spear, 2000). Neither biotite nor plagioclase shows internal compositional zoning or systematic variation between leucosome and matrix domains. Biotite has $X_{\mathrm{Mg}}\left[=\mathrm{Mg} /\left(\mathrm{Mg}+\mathrm{Fe}^{2+}\right)\right]$ of $0.52-0.59$, although is more magnesian $(\sim 0.68)$ when in contact with garnet porphyroblast outer rims (Fig. 4b). Plagioclase exhibits a restricted range in $X_{\mathrm{An}}[=\mathrm{Ca} /(\mathrm{Ca}+\mathrm{Na}+\mathrm{K})]$ of $0.32-0.35$ (Table 1 ), but is partially saussuritised, indicating some degree of retrograde alteration. K-feldspar exists exclusively in the leucosome and is almost pure orthoclase $\left(X_{\mathrm{Or}}[=\mathrm{K} /(\mathrm{Ca}+\mathrm{Na}+\mathrm{K})]\right.$ of 0.98 ; Table 1).

Mafic migmatite samples CL02, CL03, and CL10 are composed of a garnet-, amphibole-, and clinopyroxene-rich matrix that hosts more-or-less stromatic, centimetre-scale quartz- and plagioclase-dominated leucosomes (Fig. 2a). Accessory K-feldspar, ilmenite, apatite, and zircon also occur in each sample. The proportion of leucosome varies significantly within mafic migmatite samples across the Cairn Leuchan region, ranging from less than 5\% (Fig. 2a) to over 30\%. Samples CL02, CL03, and CL10 were all collected from outcrops containing between $10 \%$ and $30 \%$ leucosome, with proportions in each hand sample approximately matching those of the outcrop from which they were collected. Large subhedral clinopyroxene porphyroblasts up to $\sim 1-2 \mathrm{~cm}$ in diameter occur in many leucosome segregations (Fig. 3b) and contain no inclusions or major-element internal zoning. Minor amphibole may be present at their rims. Matrix clinopyroxene grains are typically small $(<0.5 \mathrm{~cm})$ and have anhedral to subhedral morphologies, but similar compositions to leucosome porphyroblasts $\left(X_{\mathrm{Mg}}=0.56-0.65 \mathrm{in}\right.$ the matrix and $0.54-0.61$, for porphyroblasts). All grains have $\mathrm{Na}<0.06$ cations per formula unit (cpfu) and $\mathrm{Al}<0.23 \mathrm{cpfu}$ for a six-oxygen recalculation (Table 1); thus, are diopside/augite (Morimoto et al., 1988). Amphibole is dark-brown in thin section, lacks inclusions, exhibits $\sim 120^{\circ}$ angles at three-phase junctions (Fig. 3c-d), and shows no substantial compositional zoning or variation either between samples or within different petrographic settings in the same sample. All analysed grains have $\mathrm{Si}=6.26-6.56 \mathrm{cpfu}, \mathrm{Na}$ $=0.31-0.56 \mathrm{cpfu}, \mathrm{Ti}=0.19-0.29 \mathrm{cpfu}$, and $X_{\mathrm{Mg}}=0.42-0.56$ for a twenty-three-oxygen recalculation (Table 1); thus are mostly ferropargasite/tschermakite (Leake et al., 1997, 2004). Matrix plagioclase has $X_{\mathrm{An}}=0.37-0.51$ and leucosome grains have $X_{\mathrm{An}}=0.32-0.54$ (Table 1).

Garnet occurs in the matrix of samples CL02, CL03, and CL10 as small subhedral porphyroblasts $\sim 0.1-0.5 \mathrm{~cm}$ in diameter, which contain inclusions of quartz. These porphyroblasts only show minor compositional differences between grains, with cations mostly within the range $\mathrm{Alm}_{55-63} \operatorname{Prp}_{11-16} \mathrm{Grs}_{20-30} \mathrm{Sps}_{2-4}$, although individual crystals lack 
any systematic internal zoning from core to rim. Leucosome garnet is typically subhedral to euhedral, and comprises $>80 \%$ volume of the assemblage in garnetite veins, with the remainder being dominantly quartz and plagioclase with minor clinopyroxene and/or amphibole (Fig. 3d). Garnetite-vein feldspar, clinopyroxene, and amphibole have compositions largely indistinguishable from matrix-domain equivalents (Table 1). Garnet grains within these veins mostly have similar compositions to those in the matrix (Fig. 4a), although X-ray mapping of a typical accumulation (Fig. 5) revealed that some cores are strongly enriched in $\mathrm{Mn}\left(\mathrm{Sps}_{10-12}\right.$ vs $\left.\mathrm{Sps}_{2-5}\right)$ and $\mathrm{Ca}\left(\mathrm{Grs}_{30-35} \mathrm{vs}_{\mathrm{Grs}_{22-30}}\right)$, and depleted in Fe and Mg (Table 1). These high-Mn grains show no optical or morphological differences from adjacent Mn-poor grains, and may represent the earliest-formed garnet in the rock that preferentially incorporated $\mathrm{Mn}$ (and $\mathrm{Ca}$ ) into their cores. Because garnet more readily partitions Mn over other coexisting phases in mafic migmatites (e.g. pyroxene, amphibole, ilmenite: Hall, 1985; Pownceby, Wall, \& O'Neill, 1987), later-formed porphyroblasts would have grown from a relatively Mn-depleted matrix reservoir and so exhibit significantly lower spessartine contents.

\section{THERMOBAROMETRY}

Phase equilibrium modelling was performed in order to provide new constraints on the $P-T$ conditions of metamorphism reached by these semipelitic and mafic Cairn Leuchan migmatites. Calculations were undertaken for all rock types in the 10-component NCKFMASHTO $\left(\mathrm{Na}_{2} \mathrm{O}-\mathrm{CaO}-\mathrm{K}_{2} \mathrm{O}-\mathrm{FeO}-\mathrm{MgO}-\mathrm{Al}_{2} \mathrm{O}_{3}-\mathrm{SiO}_{2}-\mathrm{H}_{2} \mathrm{O}-\mathrm{TiO}_{2}-\mathrm{O}_{2}\right)$ system using THERMOCALC version 3.45i (Powell \& Holland, 1988) and the internally consistent thermodynamic dataset of Holland and Powell (2011) (update ds62, 6 February, 2012). Equilibria for semipelite sample CL01 were calculated using the $a-x$ relations of White et al. (2014a), and mafic migmatite samples CL02 and CL03 used the following $a-x$ relations: melt, augite, and hornblende (Green et al., 2016); garnet, orthopyroxene, biotite, and chlorite (White et al., 2014a); olivine and epidote (Holland \& Powell, 2011); magnetite-spinel (White et al., 2002); ilmenite-hematite (White, Powell, Holland, \& Worley, 2000); C̄̄ plagioclase and K-feldspar (Holland \& Powell, 2003). Pure phases comprised albite, quartz, rutile, sphene, and aqueous fluid $\left(\mathrm{H}_{2} \mathrm{O}\right)$. Sample CL10 was not modelled using this technique owing to the presence of abundant garnetite veins in the hand sample, which may not be in equilibrium with the host (see section 6.1).

Titration was performed in order to determine individual $\mathrm{FeO}$ and $\mathrm{Fe}_{2} \mathrm{O}_{3}$ contents for each sample (Table 2), thus enabling bulk-rock $X_{\mathrm{Fe}^{3+}}$ ratios $\left[=\mathrm{Fe}^{3+} /\left(\mathrm{Fe}^{2+}+\mathrm{Fe}^{3+}\right)=\right.$ $\left.\left.(2 \times \mathrm{O}) / \mathrm{FeO}^{\text {tot }}\right)\right]$ to be produced for modelling, although these values were treated as 
maxima owing to potential post-metamorphic oxidation during exposure at the Earth's surface and due to oxidation that may occur during the crushing procedure. For sample CL01, the $X_{\mathrm{Fe}^{3+}}$ value was reduced from the measured value of 0.26 to 0.10 , as the former predicted hematite and magnetite at peak $P-T$ conditions instead of ilmenite, which is present in the rock instead. Bulk compositions were also adjusted for the presence of accessory apatite in each sample, which resulted in minor reductions in normalised $\mathrm{CaO}$ contents from measured values of around $0.1-0.2 \mathrm{~mol} \%$. The bulk $\mathrm{H}_{2} \mathrm{O}$ content used for modelling of each lithology was estimated from the LOI, which best represents that in the bulk composition present during peak metamorphism, assuming that the samples were not affected by any retrograde alteration and hydration. The bulk compositions used for phase diagram construction (in mol. \% oxide) are given in Table 3.

\subsection{Mafic migmatite samples CL02 and CL03}

Individual $P-T$ pseudosections calculated for samples CL02 and CL03 are shown in Figs 6a and 6b, respectively. The assemblages of L-Grt-Hbl-Kfs-Aug-Pl-Ilm-Qtz (CL02) and L-Grt-Hbl-Aug-Pl-Ilm-Qtz (CL03) observed in each sample were calculated to occur at $P-T$ conditions of $\sim 825-880{ }^{\circ} \mathrm{C}$ and $\sim 8-12 \mathrm{kbar}$ (Fig. 6a-b; bold text, orange fields), which thus likely represent conditions of peak (or near-peak) metamorphism following any melt loss that may have occurred during prograde metamorphism, burial, and compaction. Minimum pressures of peak metamorphism are given by the predicted stabilisation of orthopyroxene at $\sim 7-10 \mathrm{kbar}$, which would otherwise have formed at lower pressure at the expense of garnet (Fig. 6a-b). As orthopyroxene was neither observed in the studied samples, nor has been documented elsewhere from the Cairn Leuchan or Glen Muick region, this is interpreted to be a robust constraint on the minimum conditions of peak metamorphism, especially as the pressure range over which this transition occurs $(\sim 7-9$ kbar) is similar in most metabasic compositions (Palin, White, Green, Powell, et al., 2016; Stuck \& Diener, 2018). The upper pressure limit for crystallization of the observed assemblages in samples CL02 and CL03 is delimited in both cases by the calculated appearance of rutile in place of ilmenite; however, this phase transition is known to be sensitive to minor changes in bulk-rock composition (e.g. $\mathrm{TiO}_{2}$ content; Angiboust \& Harlov, 2017) and so is not as reliable as the garnet-orthopyroxene transition. Given that previous calculations by Aoki et al. (2014a) suggested that peak pressure for Cairn Leuchan mafic migmatites was notably higher (12-14 kbar; Fig. 6a-b), a semi-independent check on the pressure of equilibration of the observed assemblage was additionally calculated using the average- $P$ (avP) function of THERMOCALC (Powell \& Holland, 1994). The avP function is a multiple-reaction technique that uses a least-squares minimisation approach 
to average pressures derived from individual mineral equilibria, taking into account both their uncertainties and correlations (Green, 2017; Powell \& Holland, 2008; Ziberna, Green, \& Blundy, 2017). Critically, it does not rely upon definition of a bulk-rock composition, which may be difficult to constrain accurately at any one time in open systems (Guevara \& Caddick, 2016; Palin, Weller, Waters, \& Dyck, 2016), but has notably higher precision and accuracy than other similar conventional thermobarometers (Powell \& Holland, 2008).

Average- $P$ calculations for sample CL02 considered the assemblage garnet, clinopyroxene, hornblende, ilmenite, and quartz, and produced six independent reactions between end members. Within the temperature range $700-950{ }^{\circ} \mathrm{C}$, calculated pressures for CL02 varied from $7.6 \mathrm{kbar}$ to $10.3 \mathrm{kbar}$ (Table 4), with typical 1 S.D. uncertainties of $\sim 1.2$ kbar. Each data point in this range showed a significant fit value below the minimum cutoff for $95 \%$ confidence, indicating that this result is statistically robust. For sample CL03, the same assemblage produced seven independent reactions between end members, and pressures ranged from $7.4 \mathrm{kbar}$ to $10.3 \mathrm{kbar}$ over the same temperature interval (Table 4) within $95 \%$ confidence. Pressure ranges defined by these average values and associated 1 S.D. uncertainties are shown in relation to calculated phase equilibria on Fig. 6 as grey bands that have positive $\mathrm{d} P / \mathrm{d} T$ slopes. In both cases, the pressures recorded by avP barometry intersect the $P-T$ conditions that define the observed assemblage fields at their lower-pressure ends, indicating that pressures of around 9 kbar are most appropriate for final crystallisation at the solidus.

The upper temperature limits for equilibration of the observed mineral assemblages are defined in CL02 by the destabilisation of K-feldspar at $\sim 880{ }^{\circ} \mathrm{C}$ and subsequently quartz at $\sim 900{ }^{\circ} \mathrm{C}$ (Fig. 6a), and in CL03 by the loss of hornblende at $\sim 870-890{ }^{\circ} \mathrm{C}$ (Fig. 6b). Lower temperature limits in each sample are defined by the positions of their solidi, although the measured water contents of $2.66 \mathrm{~mol} . \%$ and $0.63 \mathrm{~mol} \%$, respectively, are insufficient to saturate either with $\mathrm{H}_{2} \mathrm{O}$, and so the solidus in each is calculated to occur at elevated temperatures of $\sim 800-860{ }^{\circ} \mathrm{C}$. The most likely cause of the low $\mathrm{H}_{2} \mathrm{O}$ contents of the samples is from the production and loss of melt (White \& Powell, 2002). The likely total melt production and the effects that melt loss may have had on preservation of the residual mineral assemblage in the Cairn Leuchan mafic migmatites are illustrated in Fig. 7a-b, which shows isobaric $T-X$ pseudosections calculated for sample CL03. While samples CL02 and CL03 are mineralogically similar, the latter has a relatively Fe-rich ( $X_{\mathrm{Mg}}$ $=0.34$; Table 3 ) and $\mathrm{H}_{2} \mathrm{O}$-poor (0.63 mol. \%; Table 3 ) bulk composition compared to the former, which is reflected in its relatively higher proportion of garnet and diopside (e.g. Fig. 3c) and smaller proportion of leucosome $(\sim 10 \%)$ in outcrop and hand sample. CL03 is thus assumed to represent a more melt-depleted sample than CL02, and was used to investigate likely melt production and the effects of melt loss via melt re-integration to 
produce a broadly reasonable protolith composition (White, Powell, \& Halpin, 2004).

The compositional axes on Fig. 7 represent a continuum between the measured (melt-depleted) bulk composition for sample CL03 on the left hand side (i.e. 0\% melt re-integrated) and a bulk composition representative of 30 mol. $\%$ melt added to the measured bulk composition on the right hand side (i.e. 30\% melt re-integrated). The composition of melt added back to the measured bulk composition in this calculation was that in equilibrium with the observed solid assemblage at 9 kbar and $875^{\circ} \mathrm{C}$ (cf. Fig. 6b). This melt re-integrated bulk composition is given in Table 3. With increasing proportions of re-integrated melt, the solidus temperature decreases until the fluid-saturated solidus is reached at approximately $25 \%$ melt re-integrated to the measured bulk composition (Fig. 7). Depending on how much aqueous fluid was present at the onset of melting and the exact $P-T$ conditions of peak metamorphism, the model protolith could therefore have produced up to 25-30\% melt under prograde closed -system conditions (red star).

Although the approach taken here is a relatively simple one of a single re-integrated melt composition, the melt proportion produced is similar to that calculated for other metabasic compositions (e.g. Palin, White, Green, Powell, et al., 2016; Stuck \& Diener, 2018), and so is interpreted to be reliable.

\subsection{Metamorphosed semipelite sample CL01}

Phase equilibrium modelling calculations were additionally undertaken on semipelitic migmatite sample CL01 (Fig. 8), which was collected from an outcrop adjacent to mafic migmatite samples CL02 and CL03 (Fig. 2), and so must have experienced the same tectonothermal history. The $P-T$ pseudosection for CL01 shown in Fig. 8a exhibits a calculated fluid-saturated solidus with a negative slope between $650-700{ }^{\circ} \mathrm{C}$ and $4-12 \mathrm{kbar}$. The interpreted preserved assemblage of Grt-Bt-Ilm-Sill-Pl-Qtz plus melt occurs up to $P-T$ conditions of $\sim 7-8 \mathrm{kbar}$ and $\sim 830-840{ }^{\circ} \mathrm{C}$. A field matching this assemblage is delimited on the calculated pseudosection at higher pressure by the stabilisation of kyanite in place of sillimanite, at higher temperature by the loss of biotite from the stable assemblage, and at lower pressure by the appearance of cordierite (Fig. 8a), which is not present in the sample.

Where assemblage fields span wide ranges in $P-T$ conditions, tighter constraints on the conditions of peak metamorphism can typically be provided by correlating observed and predicted proportions of key temperature- or pressure-dependent phases (Powell \& Holland, 2008). The modal proportion of biotite in sample CL01, which is shown in Fig. 8a to be highly temperature-sensitive, provides the best match at the uppermost limit of this peak assemblage field (e.g. $820-840{ }^{\circ} \mathrm{C}$ and $6-8 \mathrm{kbar}$ ), with only $\sim 3-4 \%$ biotite observed 
in thin section (e.g. Fig. 3a). This result for peak metamorphism would provide the closest correlation to the peak $P-T$ conditions derived from samples CL02 and CL03 (Fig. 8a), although they would still be at slightly lower grade. However, the observed phase proportions in sample CL01 would be expected to have been frozen-in upon crossing the solidus during cooling and exhumation; here calculated to occur at $\sim 680-690{ }^{\circ} \mathrm{C}$ and $5-7$ kbar (Fig. 8a), which is also discrepant to the proportion of leucosome present in metasedimentary units in the Cairn Leuchan area commonly observed to be up to $30 \%$ (Fig. 2b).

The discrepancy between the apparent $P-T$ conditions of the semipelite sample and the metabasic rocks likely arises from the relatively high $\mathrm{H}_{2} \mathrm{O}$ content derived from the measured LOI in CL01 (2.00 wt.\%; Table 3), which is sufficient to saturate the solidus and is notably higher than that expected from a high-grade migmatite that has faithfully preserved its peak metamorphic assemblage (White \& Powell, 2002, 2010). Given the relatively low observed biotite content and the absence of other amphibolite-facies hydrous minerals, it is likely the measured LOI values do not directly record the actual $\mathrm{H}_{2} \mathrm{O}$ content in the rock during metamorphism, likely due (in part) to the presence of saussuritisation of plagioclase feldspar in the matrix. Calculated phase equilibria that would occur in sample CL01 bulk compositions at $7 \mathrm{kbar}$ with a reduced $\mathrm{H}_{2} \mathrm{O}$ content are shown in a $T-M \mathrm{H}_{2} \mathrm{O}$ pseudosection in Fig. 8b. Furthermore, as argued in White and Powell (2002), the preserved assemblage in suprasolidus rocks is likely to be that at the solidus during cooling, rather than necessarily the highest temperature attained. Thus, we cannot preclude the possibility that the peak conditions reached were in a higher- $T$ biotite-absent assemblage and that the preserved biotite is retrograde, which would suggest that all analysed samples experienced a similar metamorphic history, as implied by their close field association.

Alternatively, biotite stability may be extended to higher grade due to the incorporation of elements $(\mathrm{F}, \mathrm{Cl})$ that are not considered in the model system used (Petersen, Essene, \& Peacor, 1982).

\section{U-PB ZIRCON GEOCHRONOLOGY}

The age of high-grade metamorphism in the Cairn Leuchan area was determined via $\mathrm{U}-\mathrm{Pb}$ geochronology performed on zircon separated from semipelitic migmatite CL01, and mafic migmatites CL02 and CL03. Each sample was crushed, their fractions washed and sieved, and zircon separated using standard magnetic and density techniques. Individual grains were hand-picked from these fractions under a binocular microscope, mounted in epoxy, and ground down to expose their cores. This mount was then examined on a JEOL 
JXA-8200 electron microprobe using the same operating conditions described above for mineral compositional analysis to obtain cathodoluminescence (CL) images, which were used to identify any internal structures and aided the choice of spot placement for laser ablation work (cf. Corfu, Hanchar, Hoskin, \& Kinny, 2003).

All geochronological analyses were performed at the Institute for Geosciences, Johannes Gutenberg University of Mainz, Germany, on a Agilent 7500ce quadrupole inductively coupled plasma mass spectrometer (ICP-MS) coupled with a ESI NWR193 laser ablation system equipped with a $\mathrm{TwoVol}^{2}$ ablation cell. Laser ablation was performed using a $30 \mu \mathrm{m}$ spot size, $10 \mathrm{~Hz}$ frequency, and a $2.8 \mathrm{~J} / \mathrm{cm}^{2}$ fluence. Twenty-second-long background measurements were followed by a $30 \mathrm{~s}$ ablation time and $20 \mathrm{~s}$ washout. All isotopic sample data were normalised to the primary zircon reference material GJ1 (Jackson, Pearson, Griffin, \& Belousova, 2004), with secondary reference materials 91500 (Wiedenbeck et al., 1995) and Plešovice (Sláma et al., 2008) used as quality controls. Data processing and uncertainty propagation was performed by an in-house Excel spreadsheet.

All U-Pb sample data were interpreted using Tera-Wasserburg plots, which provide higher-resolution interpretations of Phanerozoic age data than conventional Wetherill plots, and all calculations were performed using the Isoplot MS Excel add-in (Ludwig, 2003). Regressions assumed a ${ }^{207} \mathrm{~Pb} /{ }^{206} \mathrm{~Pb}$ ratio of $0.83 \pm 0.02$ (Stacey \& Kramers, 1975). Calculated ${ }^{238} \mathrm{U} \_{ }^{206} \mathrm{~Pb}$ ages are accurate to $\sim 2-3 \%$ according to contemporaneous measurement of primary and secondary standards, which produced ${ }^{238} \mathrm{U}-206 \mathrm{~Pb}$ ages of $610.8 \pm 2.8$ Ma for GJ1 (c. 609 Ma; Jackson et al., 2004), $1064.9 \pm 5.2$ Ma for 91500 (1065 \pm 1 Ma; Wiedenbeck et al., 1995), and $338.0 \pm 1.6$ Ma for Plešovice (337 \pm 1 Ma; Sláma et al., 2008). All ellipses on Tera-Wasserburg plots and uncertainties are given at the $2 \sigma$ level. All U-Pb geochronological data are given in Table S1 in the Supplementary Information.

\subsection{Results and interpretations of age data}

Zircon separated from semipelitic migmatite sample CL01 was large ( 50-200 $\mu \mathrm{m})$, subhedral or prismatic in shape, and commonly contained concentric internal zoning in core domains. Such morphological features are typical of magmatic zircon (Corfu et al., 2003). Sixty-eight spot analyses were obtained from 27 grains (Table S1), and showed a wide range of lower-intercept ${ }^{238} \mathrm{U}-{ }^{206} \mathrm{~Pb}$ ages between c. $2400 \mathrm{Ma}$ and c. $530 \mathrm{Ma}$ (Fig. 9a). A significant proportion of analyses were closely clustered at a concordia age of 1100-875 Ma, although no coherent populations could be determined within this group and most analyses showed some minor degree of discordance. The absence of Grampian (Ordovician) ages in these zircons may appear to support previous arguments that the Cairn Leuchan migmatites represent Precambrian basement (Ramsay \& Sturt, 1979; Read, 
1955; Smith et al., 2002; Sturt et al., 1977; Viete et al., 2010); however, thin, homogenous, and low-CL rims occur on many of the analysed zircon grain cores. Their small widths $(<5-10 \mu \mathrm{m})$ precluded effective geochronological analysis via LA-ICP-MS, although such overgrowths are likely to be of metamorphic origin, as similar features $(<1 \mu \mathrm{m}$ in width) in Glen Muick metapelites were dated by Vorhies et al. (2013) via SIMS U-Pb depth profiling techniques to give metamorphic ages of c. 474 Ma. The ages for sample CL01 are thus interpreted as representing the time of crystallisation of earlier (pre-Caledonian) magmas, which were subsequently eroded and their zircons deposited within a Tethyan sedimentary succession that was later metamorphosed to become the Dalradian Series. Metamorphism of this succession to produce the high-grade migmatites observed in the Cairn Leuchan region evidently did not allow for substantial recrystallization of these detrital grains or growth of new zircon in sample CL01.

In contrast to sample CL01, zircon grains separated from mafic migmatite samples CL02 and CL03 were small $(\sim 30-100 \mu \mathrm{m})$, anhedral or subhedral in shape, and typically contained xenocrystic or oscillatory zoned cores surrounded by homogenous rims of variable width. Such textures are often inferred to be indicative of metamorphic overgrowths on - or the recrystallisation of rims of - detrital or magmatic zircon cores (Corfu et al., 2003). Fifty-five spot analyses were obtained from 39 grains in sample CL02, and 44 spot analyses were obtained from 26 grains in sample CL03 (Table S1). Lower-intercept ${ }^{238} \mathrm{U}-206 \mathrm{~Pb}$ ages for sample CL02 ranged from c. $1580 \mathrm{Ma}$ to c. $320 \mathrm{Ma}$, although the majority of metamorphic rim analyses clustered at c. 610-480 Ma (Fig. 9b). A similar result was obtained for sample CL03, although there were very few Precambrian ages in comparison to samples CL01 and CL02. Here, lower-intercept ${ }^{238} \mathrm{U}-{ }^{206} \mathrm{~Pb}$ ages ranged from c. $620 \mathrm{Ma}$ to c. $470 \mathrm{Ma}$, with most younger than c. $540 \mathrm{Ma}$ (Fig. 9c). Distinct populations within these clusters could not be statistically determined within required confidence limits, meaning that no specific ages could be interpreted for the timing of metamorphic zircon growth. Nonetheless, they unequivocally show that metamorphism of the mafic migmatites in the Glen Muick region is of Grampian age (c. 470 Ma; Vorhies et al., 2013), not Mesoproterozoic as has been suggested by some recent studies (e.g. c. 1000 Ma; Viete et al., 2014).

Lithostratigraphic work performed on the Dalradian Supergroup shows that a major phase of volcanic activity with N-MORB geochemical affinity occurred at c. 630-620 Ma during deposition of the Easdale Subgroup onto the eastern margin of Laurentia (Fettes et al., 2011; McCay, Prave, Alsop, \& Fallick, 2006; Prave, Fallick, Thomas, \& Graham, 2009). This series of rocks directly underlies the Cairn Leuchan metabasite-bearing Crinan Subgroup of the Upper Dalradian Series (Stephenson et al., 2013b), showing that the protoliths of the mafic migmatites studied herein must therefore be younger. We interpret 
that they most likely formed during a subsequent period of volcanism at 570 Ma associated with passive-margin extension (Fitton, 2007), synchronous with deposition of the Crinan Subgroup and prior to the onset of Iapetus Ocean closure (Fettes et al., 2011; Goodman \& Winchester, 1993; Smith et al., 2002).

\section{DISCUSSION AND CONCLUSIONS}

Semipelitic and mafic rocks exposed in the Cairn Leuchan/Glen Muick region of northeast Scotland preserve the highest-grade metamorphic $P-T$ conditions recognised within the Scottish Dalradian so far (e.g. Baker \& Droop, 1983; Vorhies \& Ague, 2011), and thus provide important constraints on the nature of regional-scale Barrovian metamorphism during the Ordovician Grampian Orogeny. Although there has been long-standing debate as to the origin and age of the metabasic rocks from the Glen Muick area, recent stratigraphic work by Stephenson et al. (2013b) concluded that all Cairn Leuchan lithologies must belong to the Crinan Subgroup of the Upper Dalradian Series, as opposed to representing Precambrian basement (as previously claimed: Ramsay \& Sturt, 1979; Read, 1955; Smith et al., 2002; Sturt et al., 1977; Viete et al., 2010). This structural interpretation is confirmed by U-Pb zircon ages of c. $540 \mathrm{Ma}$ to c. $470 \mathrm{Ma}$ presented in this work, which demonstrate that the rocks underwent high-grade metamorphism and partial melting during the Cambro-Ordovician, not the Mesoproterozoic (cf. Viete et al., 2014).

\subsection{Partial melting and the formation of garnetite veins}

The metasedimentary and metabasic lithologies exposed on the hill of Cairn Leuchan show extensive and varied petrographic evidence for having partially melted, both at the outcrop/hand sample (Fig. 2a-f) and thin section (Fig. 3b) scale. A particularly widespread feature of mafic migmatites in the area is centimetre-scale veins composed almost entirely (>80\%) of garnet (Fig. 3d). These veins, which also contain minor quartz, plagioclase, amphibole, and clinopyroxene, are intimately associated with garnet-absent (or garnet-poor) leucosomes, commonly laterally transitioning into each other over relatively short length scales (Fig. 2e). Electron microprobe analyses of garnets in these veins shows that their major-element compositions are similar to grains in the host mafic migmatite matrix, and to porphyroblasts in relatively garnet-poor leucosome segregations (Fig. 4a, Table 1), suggesting that all had a common petrogenesis.

Monomineralic segregations can form in metamorphic rocks in response to either diffusional or physical processes. In the former case, chemical potentials can be established

This article is protected by copyright. All rights reserved. 
between melt-rich domains and melt-poor residues, driving diffusional interactions between the two (White \& Powell, 2011; White, Powell, \& Baldwin, 2008; White et al., 2004). For example, upon cooling from peak metamorphism, the chemical potential of $\mathrm{H}_{2} \mathrm{O}$ can become higher in melt segregations than in the matrix, and diffusion of water from the former to the latter can promote spatially focused crystallisation of anhydrous products from the melt and crystallisation of hydrous products within the residue (Waters, 1988; White \& Powell, 2010). Alternatively, the injection of melt with a low activity of $\mathrm{H}_{2} \mathrm{O}$ has been inferred to have driven the formation of garnet-rich bands in metagabbro (Daczko, Clarke, \& Klepeis, 2001). While this diffusion-driven process could theoretically account for the garnetite veins observed at Cairn Leuchan from a petrological standpoint, their laterally discontinuous nature and abrupt transitioning into garnet-poor leucosome (Fig. 2e) cannot be easily explained by this mechanism.

An alternative scenario is that the garnet-rich segregations formed as a result of physical processes; for example, involving the transport and spatial concentration/aggregation of individual garnet grains, and/or the removal of an interstitial fluid phase, such as melt. The presence of hornblende, clinopyroxene, and plagioclase within garnetite veins that have identical major-element compositions to those grains from garnet-poor/absent leucosomes is not diagnostic, but supports the hypothesis that the garnetite veins now represent melt-depleted leucosomes. This is further shown by field evidence for local melt migration and/or extraction over length scales larger than that of the veins themselves (e.g. boudinage/collapse structures; Fig. 2f).

Figure 10 shows a schematic petrological interpretation for the formation of these garnetite veins, based on the range of field observations, and petrological and geochemical data described above. During prograde metamorphism at lower amphibolite-facies conditions (prior to partial melting), initial garnet growth would likely have been characterised by the nucleation of few, small, widely distributed, and Mn-rich grains (Fig. 10a: Hollister, 1966). Mn-depleted volumes would have developed around each nucleus (Carlson, 2002), as indicated schematically by dashed lines. The preferential incorporation of $\mathrm{Mn}$ (and $\mathrm{Ca}$ ) into early-formed garnet cores would have led to a change in the composition of the rock matrix to lower Mn contents. Later garnet growth would have formed grains with lower Mn contents or developed as rims on these high-Mn cores (Fig. 10b), as observed in these Cairn Leuchan samples (Fig. 5).

During heating at upper amphibolite- to granulite-facies conditions, tonalitic partial melt would likely have formed alongside additional garnet and/or clinopyroxene at the expense of hornblende and quartz (Palin, White, \& Green, 2016). Spatial focussing of partial melt around garnet is probable in this scenario, as garnet is a reaction product (Fig. 
10c: White et al., 2004). Continued metamorphism to peak (or near-peak) upper amphibolite-/high-pressure granulite-facies conditions of $\sim 9 \mathrm{kbar}$ and $\sim 840{ }^{\circ} \mathrm{C}$ (cf. Fig. 6 ) would have been associated with continued garnet and clinopyroxene growth and melt production (Fig. 10d). At some point, sufficient melt would have been produced to allow deformation-driven segregation into leucosomes (cf. Renner, Evans, \& Hirth, 2000; Rosenberg \& Handy, 2005; Vigneresse, Barbey, \& Cuney, 1996). This syn-metamorphic deformation (cf. Fig. 2f) would have induced melt extraction along pressure gradients, accompanied by the collapse of some of the melt network (e.g. Bons et al., 2004; Bons, Druguet, Castaño, \& Elburg, 2008; Diener, White, \& Hudson, 2014). During melt drainage, some garnet grains were likely entrapped in melt and carried along with it for some distance (e.g. Brown, Brown, Carlson, \& Denison, 1999). Physical aggregation of grains could potentially occur along melt networks at narrow points forming 'log-jams' of garnet. For both grains that remained more or less in situ and those that were transported short distances with the melt, the eventual drainage of melt from the leucosome network would have left behind these solid porphyroblasts as a concentrated deposit (Fig. 10e), accounting for the identical major-element compositions of garnet, clinopyroxene, and amphibole within garnetite veins and those grains present in the matrix (Fig. 4 and Table 1). Limited retrogression of these mafic phases suggests that considerable amounts of melt escaped (White \& Powell, 2002), as indicated by the generally low $\mathrm{H}_{2} \mathrm{O}$ contents of both studied mafic migmatite samples. The general features of the textural evolution described above are consistent with garnetite-leucosome associations and internal structures observed in the field, simplified petrological traces of which are given in Figs $10 \mathrm{f}$ and $10 \mathrm{~g}$.

Following on from these petrologic arguments for melt production and extraction, it is natural to ask the where, then, did this volume of melt go? The timing and nature of magmatism in the Grampian Terrane has been well constrained to a c. 10 Myr period, with bimodal gabbroic and granitic intrusions emplaced from c. $475 \mathrm{Ma}$ to c. $465 \mathrm{Ma}$ (Viete et al., 2013, and references therein). Despite intense study, however, there are no known intrusive bodies of tonalitic composition (cf. Fig. 3b) of Ordovician age within the Scottish Dalradian that may represent higher-level accumulations of this lost melt.

However, as metabasic rocks appear to comprise only very small proportion of the known Dalradian outcrops (Stephenson et al., 2013b), it is likely that any melt produced and extracted from such lithologies - including those exposed at Cairn Leuchan - mixed with much larger volumes of more granitic melt produced by metasedimentary lithologies, rather than forming discrete intrusions. 


\subsection{Comparison with previous studies}

A recent study by Aoki et al. (2014a) suggested that the peak metamorphic $P-T$ conditions for the Cairn Leuchan mafic migmatites described herein were $~ 12-14$ kbar at $\sim 770-800{ }^{\circ} \mathrm{C}$, and that they experienced amphibolite-facies retrograde equilibration at $\sim 5-8 \mathrm{kbar}$ and $\sim 580-700{ }^{\circ} \mathrm{C}$ during exhumation. They interpreted these $P-T$ data to show that high-grade (e.g. kyanite- and sillimanite-zone) Grampian Terrane Barrovian metamorphism was in fact a retrograde feature imprinted onto rocks that had previously been subducted and metamorphosed to blueschist-, eclogite-, and high-pressure granulite-facies metamorphism during the early stages of arc-continent collision. These peak $P-T$ conditions reported by Aoki et al. (2014a) differ from those determined in this work, which show that the Cairn Leuchan region reached higher granulite-facies peak temperatures (at least $840{ }^{\circ} \mathrm{C}$ ), but at lower peak pressures ( 9 kbar) that are explicable without calling upon subduction.

While Aoki et al. (2014a) employed phase equilibrium modeling to determine the $P-T$ history of the Cairn Leuchan lithologies, specifically in order to avoid the pitfalls commonly associated with conventional thermobarometry (Frost \& Chacko, 1989), there were numerous shortcomings in their model setup. First and foremost, calculations were undertaken in the simplified $\mathrm{MnO}-\mathrm{Na}_{2} \mathrm{O}-\mathrm{CaO}-\mathrm{FeO}-\mathrm{MgO}-\mathrm{Al}_{2} \mathrm{O}_{3}-\mathrm{SiO}_{2}-\mathrm{H}_{2} \mathrm{O}$ (MnNCFMASH) compositional system, which lacks important components (such as $\mathrm{Fe}_{2} \mathrm{O}_{3}$ ) that can strongly affect phase equilibria in mafic rocks (Diener \& Powell, 2010). For example, calculations by Green et al. (2016) and Palin, White, Green, Powell, et al. (2016) suggest that the stability of garnet can be decreases up-temperature by over $50{ }^{\circ} \mathrm{C}$ at $\sim 10$ kbar for an increase in bulk-rock $\mathrm{Fe}_{2} \mathrm{O}_{3}$ content of just $10 \%$. In addition, Aoki et al. (2014a) used older generations of $a-x$ relations for many minerals exhibiting solid solution, including garnet from Holland and Powell (1998), clinopyroxene from Holland and Powell (1996), and clinoamphibole from Dale, Holland, and Powell (2000). These $a-x$ relations are unsuitable for examining phase equilibria in high-temperature mafic rocks and have been superceded by more realistic parameterisations (e.g. Green et al., 2016). Further, unlike in this study, Aoki et al. (2014a) did not consider an $a-x$ relation for silicate melt (cf. Green et al., 2016), and so were unable to consider the effects of melt loss, which is of considerable importance in the petrological evolution and stabilisation of granulite terranes (Brown, 2007; Diener et al., 2014; Sawyer, 2001; White, Palin, \& Green, 2016; White \& Powell, 2002). The results of this work therefore echo those stated by previous workers (e.g. Huang, Brown, Guo, Piccoli, \& Zhang, 2018; Powell \& Holland, 2008) that the best chance of deriving realistic and reliable constraints on the tectonothermal evolution of high-grade metamorphic rocks can be achieved by employing the most up-to-date $a-x$ 
relations and thermodynamic dataset in the most comprehensive compositional system relevant to the rocks under study.

\subsection{Implications for high-grade metamorphism in the Grampian Terrane}

The cause and nature of Barrovian metamorphism in the Grampian Terrane has long-been speculated upon, and remains a topic of continued debate today (e.g. Viete et al., 2014). Pioneering thermo-mechanical models used to account for such regional-scale metamorphism considered thrust-related crustal thickening, internal radioactive heating, and subsequent thermal equilibration along perturbed geotherms in order to generate the middle- to upper-amphibolite-facies $P-T$ conditions that characterise these terranes (England \& Thompson, 1984; Thompson \& England, 1984). Simulations using typical values for key parameters such as thermal diffusivity, internal radiogenic heat production, and mantle heat flow require around 35-40 Myr of burial and thermal relaxation for temperatures of $\sim 650-700{ }^{\circ} \mathrm{C}$ to be reached in the middle crust (England \& Thompson, 1984; Jamieson, Beaumont, Fullsack, \& Lee, 1998; Johnson \& Strachan, 2006; Lyubetskaya \& Ague, 2010; Smye et al., 2011). While this is a sufficient period of time to account for regional metamorphism during continent-continent collision (e.g. the Himalayan-Tibetan orogeny: Palin et al., 2014; Searle, Cottle, Streule, \& Waters, 2009; St-Onge et al., 2006), the Grampian Event of the Caledonian orogeny occurred in response to the accretion of an island arc system to the Laurentian continental margin (Fig. 1; Dewey \& Mange, 1999; McKerrow et al., 2000; Soper et al., 1999), with peak metamorphism achieved after only 25 Myr (Baxter et al., 2002; Dewey, 2005; Oliver et al., 2000).

While the timescales necessary for continent-continent and arc-continent collision to achieve upper-amphibolite-facies metamorphic conditions differ only slightly ( 10-15 Myr: Brown et al., 2011), our phase diagram modelling suggests that peak Grampian Event metamorphic conditions in the Glen Muick region reached at least $\sim 840{ }^{\circ} \mathrm{C}$ at $\sim 9 \mathrm{kbar}$ (Fig. 6a-b). Achieving such high temperatures would not be possible within the $\sim 25 \mathrm{Myr}$ period often cited for Barrovian metamorphism in the Grampian terrane in the absence of additional mechanisms that can locally supply additional heat, such as mantle heat advection (Viete et al., 2010), sheeted magmas emplaced along shear zones (Viete et al., 2011), unusually high radiogenic heat production (Huerta, Royden, \& Hodges, 1998), or regional-scale contact metamorphism owing to voluminous, syn-peak magma intrusion in the middle or lower crust (Viete et al., 2013).

The Cairn Leuchan/Glen Muick region represents a significant thermal and barometric high within the Grampian Terrane (Baker, 1985), with both temperatures and pressures reported for peak metamorphism decreasing rapidly over short distances in all directions. 
Some authors have proposed that metamorphic field gradients showing peak $P-T$ conditions in each of the individual chlorite-, biotite-, garnet-, staurolite-, kyanite-, and sillimanite-grade Barrow zones are markedly convex towards the temperature axis (Harte \& Hudson, 1979; Vorhies \& Ague, 2011). Such a pattern is unlikely to have resulted from crust solely undergoing thickening, heating, and concurrent erosion (De Yoreo, Lux, \& Guidotti, 1991; England \& Thompson, 1984; Jamieson et al., 1998), but can theoretically be accounted for by the additional influence of any of the localised sources of heat described above. Lower-sillimanite zone (Sill+Ms) units from outside of the Glen Muick region may have formed as a result of a retrograde contact-metamorphic overprint on regional-metamorphic assemblages, which reached peak temperatures of $\sim 610-690{ }^{\circ} \mathrm{C}$ at 4.5-7.5 kbar during exhumation (Baxter et al., 2002; Viete et al., 2013; Vorhies \& Ague, 2011). These upper-sillimanite zone peak conditions, however, are approximately $\sim 120{ }^{\circ} \mathrm{C}$ and $\sim 3-4$ kbar lower grade than those reported herein for the Cairn Leuchan migmatites (cf. box labelled 'Sill' on Fig. 8a). If the high-grade, high-pressure granulite-facies metamorphism at Glen Muick resulted from a similar mechanism, one may expect some kind of geological evidence for an abundance of magmatic activity in the immediate vicinity, even if this was never exposed at the surface. However, aeromagnetic and Bouguer gravity anomaly surveys of the region do not support the existence of such subsurface features (British Geological Survey, 1995a, 1995b; Smith et al., 2002), which are clearly identifiable using such remote sensing techniques elsewhere in the Grampian Terrane (e.g. the Buchan tectonic block to the northwest; Fig. 1b).

An alternative explanation for this localised thermobarometric anomaly may involve the existence of syn- or post-metamorphic structural features that uplifted deeper-seated lower-crustal units and juxtaposed them against relatively lower-grade, middle-crustal, lower-sillimanite Barrow zone units. Such a tectonic break was proposed to exist by Baker (1985), based on the existence of subsolidus, garnet- and clinopyroxene-absent, epidote-amphibolite facies metabasites exposed at Glen Girnock only a few kilometres to the west of Glen Muick (Fig. 1b). These units were metamorphosed at $\sim 680{ }^{\circ} \mathrm{C}$ (Baker \& Droop, 1983; Rao \& Johannes, 1979) and are separated from those at Glen Muick/Cairn Leuchan by a NE-SW-trending band of steeply dipping, strongly sheared serpentinite and gabbro (Baker, 1987; Bell, 1882), thought to be an offshoot of the Portsoy-Duchray Hill Lineament; a major zone of discontinuities in the Grampian Terrane running from Portsoy on the Banff coast to the Duchray Hill area in Perthshire (Goodman, 1994; Stephenson et al., 2013b). Assuming a crustal density of $3000 \mathrm{~kg} / \mathrm{m}^{3}$, our modelled peak metamorphic pressure of $\sim 9$ kbar in mafic migmatite samples CL02 and CL03 (Fig. 6) is equivalent to burial to a depth of $\sim 30 \mathrm{~km}$ under lithostatic conditions. Pressures recorded by lower-sillimanite zone units during late-stage 'contact metamorphism' ( $\sim 4.5-7.5 \mathrm{kbar})$ are 
thought to have been lower than those reached during peak burial (Vorhies \& Ague, 2011), which are assumed here to have been similar to those recorded by adjacent kyanite-grade units ( 6.5-8.0 kbar) that did not experience thermal overprinting during exhumation. These latter pressures represent burial to a maximum depth of $\sim 20-24 \mathrm{~km}$, thus implying that a notable amount of vertical displacement $(>8 \mathrm{~km})$ would have been required along this steeply dipping shear zone in order to juxtapose these units together.

Unfortunately, poor exposure has inhibited identification of field evidence for such a structural break continuing around the Glen Muick region, where it would be expected to occur on the eastern or northern margins. If present, the units exposed on the hill of Cairn Leuchan would represent deeply exhumed lower crust that marks the highest-grade metamorphic units that formed as a result of the Grampian Event, requiring re-assessment of the tectonic history of the Barrow Zones. Metasedimentary rocks currently classified as belonging to the upper amphibolite-facies 'second sillimanite' (Sill+Kfs) zone of the Barrow Zone sequence further to the west of Glen Muick (Fig. 1b) may require more detailed analysis of their thermobarometric histories using petrological modeling, as they are less likely to record true peak metamorphic conditions, as demonstrated here for sample CL01. As such, the high-grade Cairn Leuchan/Glen Muick mafic migmatites and metasediments are thus interpreted as representing a slice of exhumed Ordovician Grampian Terrane lower crust - not Precambrian basement - with their basaltic protoliths having formed during 570-Ma volcanism associated with passive-margin extension (Fitton, 2007) prior to the initiation of closure of the Iapetus Ocean (Fettes et al., 2011; Goodman \& Winchester, 1993; Smith et al., 2002).

\section{Acknowledgements}

Funding for this work was provided by the Johannes-Gutenberg University of Mainz. Elizabeth Nettleton is thanked for her support in the field, Philip Süßer is thanked for his help in zircon separation, and Isabelle Leisgang for her help in zircon picking. We thank Geoff Clarke and Jeff Marsh for two very helpful reviews that led to significant improvements. Mike Brown is thanked for his efficient editorial handling.

\section{References}

Ague, J. J., Baxter, E. F., \& Eckert Jr, J. O. (2001). High $f_{\mathrm{O}_{2}}$ during sillimanite zone metamorphism of part of the Barrovian type locality, Glen Clova, Scotland. Journal of Petrology, 42, 1301-1320.

This article is protected by copyright. All rights reserved. 
Angiboust, S., \& Harlov, D. E. (2017). Ilmenite breakdown and rutile-titanite stability in metagranitoids: Natural observations and experimental results. American Mineralogist, 102, 1696-1708.

Aoki, K., Windley, B. F., Maruyama, S., \& Omori, S. (2014a). Metamorphic P-T and retrograde path of high-pressure Barrovian metamorphic zones near Cairn Leuchan, Caledonian orogen, Scotland. Geological Magazine, 151, 559-571.

Aoki, K., Windley, B. F., Maruyama, S., \& Omori, S. (2014b). Reply to Discussion of 'Metamorphic $P-T$ and retrograde path of high-pressure Barrovian metamorphic zones near Cairn Leuchan, Caledonian orogen, Scotland' by Viete, D. R., Oliver, G. J. H. \& Wilde, S. A. Geological Magazine, 4, 759-763.

Appleby, S. K., Gillespie, M. R., Graham, C. M., Hinton, R. W., Oliver, G. J. H., Kelley, N. M., \& EIMF. (2010). Do S-type granites commonly sample infracrustal sources? New results from an integrated $\mathrm{O}, \mathrm{U}-\mathrm{Pb}$, and $\mathrm{Hf}$ isotope study of zircon. Contributions to Mineralogy and Petrology, 160, 115-132.

Atherton, M. P. (1977). The metamorphism of the Dalradian rocks of Scotland. Scottish Journal of Geology, 13, 331-370.

Baker, A. J. (1985). Pressures and temperatures of metamorphism in the eastern Dalradian. Journal of the Geological Society of London, 142, 137-148.

Baker, A. J. (1987). Models for the tectonothermal evolution of the eastern Dalradian of Scotland. Journal of Metamorphic Geology, 5, 101-118.

Baker, A. J., \& Droop, G. T. R. (1983). Grampian metamorphic conditions deduced from mafic granulites and sillimanite-K-feldspar gneisses in the Dalradian of Glen Muick, Scotland. Journal of the Geological Society of London, 140, 489-497.

Barrow, G. (1893). On an intrusion of muscovite-biotite gneiss in the South-eastern Highlands of Scotland, and its accompanying metamorphism. Quarterly Journal of the Geological Society of London, 49, 330-358.

Barrow, G. (1912). On the geology of lower Dee-side and the southern Highland Border. Proceedings of the Geologists' Association, 23(5), 274-290.

Baxter, E. F., Ague, J. J., \& De Paolo, D. (2002). Prograde temperature-time evolution in the Barrovian type-locality constrained by $\mathrm{Sm} / \mathrm{Nd}$ garnet ages from Glen Clova, Scotland. Journal of the Geological Society of London, 159, 71-82.

Bell, W. H. (1882). Notes on the geology of Deeside, near Ballater. Transactions of the Edinburgh Geological Society, 4, 201-206.

Berman, R. G. (1988). Internally-consistent themodynamic data for minerals in the system $\mathrm{Na}_{2} \mathrm{O}-\mathrm{K}_{2} \mathrm{O}-\mathrm{CaO}-\mathrm{MgO}-\mathrm{FeO}-\mathrm{Fe}_{2} \mathrm{O}_{3}-\mathrm{Al}_{2} \mathrm{O}_{3}-\mathrm{SiO}_{2}-\mathrm{TiO}_{2}-\mathrm{H}_{2} \mathrm{O}-\mathrm{CO}_{2}$. Journal of Petrology, 29, 445-522.

Bons, P. D., Arnold, J., Elburgh, M. A., Kalda, J., Soesoo, A., \& van Milligen, B. P. 
(2004). Melt extraction and accumulation from partially molten rocks. Lithos, 78, $25-42$.

Bons, P. D., Druguet, E., Castaño, L.-M., \& Elburg, M. A. (2008). Finding what is now not there anymore: Recognising missing fluid and magma volumes. Geology, 36, 851-854.

Breeding, C. M., Ague, J. J., Grove, M., \& Rupke, A. (2004). Isotopic and chemical alteration of zircon by metamorphic fluids; $\mathrm{U}-\mathrm{Pb}$ age depth-profiling of zircons from Barrow's garnet zone, northeast Scotland. American Mineralogist, 89, 1067-1077.

British Geological Survey. (1995a). Aboyne. Scotland Sheet 66W. Solid Geology. 1:50,000 [Computer software manual]. Keyworth, Nottingham.

British Geological Survey. (1995b). Ballater. Scotland Sheet 65E. Solid Geology. 1:50,000 [Computer software manual]. Keyworth, Nottingham.

Brown, D., Ryan, P., Afonso, J., Boutelier, D., Burg, J., Byrne, T., .. Zagorevski, A. (2011). Arc-Continent Collision: The Making of an Orogen. In Arc-Continent Collision (pp. 477-493). Springer.

Brown, E. H., \& Walker, N. W. (1993). A magma-loading model for Barrovian metamorphism in the southeast Coast Plutonic Complex, British Columbia and Washington. Geological Society of America Bulletin, 105, 479-500.

Brown, M. (2007). Crustal melting and melt extraction, ascent and emplacement in orogens: mechanisms and consequences. Journal of the Geological Society of London, $164,709-730$.

Brown, M. A., Brown, M., Carlson, W. D., \& Denison, C. (1999). Topology of syntectonic melt-flow networks in the deep-crust: Inferences from three-dimensional images of leucosome geometry in migmatites. American Mineralogist, 84, 1793-1818.

Carlson, W. D. (2002). Scales of disequilibrium and rates of equilibration during metamorphism. American Mineralogist, 87, 185-204.

Carty, J. P., Connelley, J. N., Hudson, N. F. C., \& Gale, J. F. W. (2012). Constraints on the timing of deformation, magmatism and metamorphism in the Dalradian of NE Scotland. Scottish Journal of Geology, 48, 103-117.

Chew, D. M., Daly, J. S., Magna, T., Page, L. M., Kirkland, C. L., Whitehouse, M. J., \& Lam, R. (2010). Timing of ophiolite obduction in the Grampian orogen. Geological Society of America Bulletin, 122, 1787-1799.

Chinner, G. A. (1960). Pelitic gneisses with varying ferrous/ferric ratios from Glen Clova, Angus, Scotland. Journal of Petrology, 1, 178-217.

Chinner, G. A. (1966). The distribution of pressure and temperature during Dalradian metamorphism. Quarterly Journal of the Geological Society of London, 122, 159-186.

Corfu, F., Hanchar, J. M., Hoskin, P. W. O., \& Kinny, P. D. (2003). Atlas of zircon 
textures. Reviews in Mineralogy and Geochemistry, 53, 469-500.

Daczko, N. R., Clarke, G. L., \& Klepeis, K. A. (2001). Transformation of two-pyroxene hornblende granulite to garnet granulite involving simultaneous melting and fracturing of the lower crust, Fiordland, New Zealand. Journal of Metamorphic Geology, 19, 549-562.

Dale, J., Holland, T. J. B., \& Powell, R. (2000). Hornblende-garnet-plagioclase thermobarometry: a natural assemblage calibration of the thermodynamics of hornblende. Contributions to Mineralogy and Petrology, 140, 353-362.

Dempster, T. (1985). Uplift patterns and orogenic evolution in the Scottish Dalradian. Journal of the Geological Society of London, 142, 111-128.

Dempster, T., Rogers, G., Tanner, P. W., Bluck, B. J., Muir, R. J., Redwood, S. D., ... Paterson, B. A. (2002). Timing of deposition, orogenesis and glaciation within the Dalradian rocks of Scotland: constraints from $\mathrm{U}-\mathrm{Pb}$ zircon ages. Journal of the Geological Society of London, 159, 83-94.

Dempster, T. J., Hudson, N. F. C., \& Rogers, G. (1995). Metamorphism and cooling of the NE Dalradian. Journal of the Geological Society of London, 152, 383-390.

Dewey, J. F. (1969). Evolution of the Appalachian/Caledonian Orogen. Nature, 222, $124-129$.

Dewey, J. F. (2005). Orogeny can be very short. Proceedings of the National Academy of Sciences of the United States of America, 102, 15286-15293.

Dewey, J. F., \& Mange, M. A. (1999). Petrography of Ordovician and Silurian sediments in the western Irish Caledonides: tracers of short-lived Ordovician continent-arc collision orogeny and the evolution of the Laurentian Appalachian-Caledonian margin. In C. Mac Niocaill \& P. D. Ryan (Eds.), Continental tectonics (Vol. 164, pp. 55-107). Geological Society of London, Special Publications.

De Yoreo, J. J., Lux, D. R., \& Guidotti, C. V. (1991). Thermal modelling in low-pressure/high-temperature metamorphic belts. Tectonophysics, 188, 209-238.

Diener, J. F. A., \& Powell, R. (2010). Influence of ferric iron on the stability of mineral assemblages. Journal of Metamorphic Geology, 28, 599-613.

Diener, J. F. A., White, R. W., \& Hudson, T. J. M. (2014). Melt production, redistribution and accumulation in mid-crustal source rocks, with implications for crustal-scale melt transfer. Lithos, 200-201, 212-225.

England, P. C., \& Thompson, A. B. (1984). Pressure-temperature-time paths of regional metamorphism I. Heat transfer during the evolution of regions of thickened continental crust. Journal of Petrology, 25, 894-928.

Fettes, D. J., MacDonald, R., Fitton, J. G., Stephenson, D., \& Cooper, M. R. (2011). Geochemical evolution of Dalradian metavolcanic rocks: implications for the 
break-up of the Rodinia supercontinent. Journal of the Geological Society of London, $168,1133-1146$.

Fitton, J. G. (2007). The OIB paradox. Geological Society of America, Special Paper, 430 , $387-412$.

Fraser, J. E., Searle, M. P., Parrish, R. R., \& Noble, S. R. (2001). Chronology of deformation, metamorphism, and magmatism in the southern Karakoram Mountains. Geological Society of America Bulletin, 113, 1443-1455.

Frost, B. R., \& Chacko, T. (1989). The granulite uncertainty principle: limitations on thermobarometry in granulites. The Journal of Geology, 97, 435-450.

Goodman, S. (1994). The Portsoy-Duchray Hill Lineament: a review of the evidence. Geological Magazine, 131, 407-415.

Goodman, S., \& Winchester, J. A. (1993). Geochemical variations within metavolcanic rocks of the Dalradian Farragon Beds and adjacent formations. Scottish Journal of Geology, 29, 131-141.

Goscombe, B. D., \& Hand, M. (2000). Contrasting $P-T$ paths in the Eastern Himalaya, Nepal: inverted isograds in a paired metamorphic mountain belt. Journal of Petrology, 41, 1673-1719.

Green, E. C. R. (2017). Metamorphic reactions and processes. In (pp. 1-12). Springer.

Green, E. C. R., White, R. W., Diener, J. F. A., Powell, R., Holland, T. J. B., \& Palin, R. M. (2016). Activity-composition relations for the calculation of partial melting equilibria for metabasic rocks. Journal of Metamorphic Geology, in press, doi: 10.1111/jmg.12211.

Guevara, V. E., \& Caddick, M. J. (2016). Shooting at a moving target: phase equilibria modelling of high-temperature metamorphism. Journal of Metamorphic Geology, 34 , 209-235.

Hall, R. P. (1985). Mg-Fe-Mn distribution in amphiboles, pyroxenes, and garnets and implications for conditions of metamorphism of high-grade early Archean iron-formation, southern West Greenland. Mineralogical Magazine, 49, 117-128.

Harris, A. L., \& Pitcher, W. S. (1975). The Dalradian Supergroup. In A. L. Harris (Ed.), A correlation of the Precambrian rocks in the British Isles (Vol. 6, pp. 52-75). Special Report of the Geological Society of London.

Harte, B., \& Hudson, N. F. C. (1979). Pelite facies series and the temperatures and pressures of Dalradian metamorphism. In A. L. Harris, C. H. Holland, \& B. E. Leake (Eds.), The Caledonides of the British Isles - Reviewed (Vol. 8, pp. 323-337). The Geological Society, London, Special Publication.

Harte, B., \& Johnson, M. R. W. (1969). Metamorphic history of Dalradian rocks in Glens Clova, Esk, and Lethnot, Angus, Scotland. Scottish Journal of Geology, 5, 54-80.

This article is protected by copyright. All rights reserved. 
Henry, D. J., Guidotti, C. V., \& Thompson, J. A. (2005). The Ti-saturation surface for low-to-medium pressure metapelitic biotite: implications for geothermometry and Ti-substitution mechanisms. American Mineralogist, 90, 316-328.

Holland, T. J. B. (2009). A program to calculate activities of mineral endmembers from chemical analyses (usually determined by electron microprobe).

http://www.metamorph.geo.uni-mainz.de/thermocalc/software/ax. Accessed, October 2015.

Holland, T. J. B., \& Powell, R. (1996). Thermodynamics of order-disorder in minerals: II. Symmetric formalism applied to solid solutions. American Mineralogist, 81, $1425-1437$.

Holland, T. J. B., \& Powell, R. (1998). An internally consistent thermodynamic dataset for phases of petrological interest. Journal of Metamorphic Geology, 16, 309-343.

Holland, T. J. B., \& Powell, R. (2003). Activity-composition relations for phases in petrological calculations: an asymmetric multicomponent formulation. Contributions to Mineralogy and Petrology, 145, 492-501.

Holland, T. J. B., \& Powell, R. (2011). An improved and extended internally consistent thermodynamic dataset for phases of petrological interest, involving a new equation of state for solids. Journal of Metamorphic Geology, 29, 333-383.

Hollister, L. S. (1966). Garnet zoning: an interpretation based on the Rayleigh fractionation model. Science, 154, 1647-1651.

Huang, G., Brown, M., Guo, J., Piccoli, P., \& Zhang, D. (2018). Challenges in constraining the P-T conditions of mafic granulites: An example from the northern TransNorth China Orogen. Journal of Metamorphic Geology, in press.

Huerta, A. D., Royden, L. H., \& Hodges, K. V. (1998). The thermal structure of collisional orogens as a response to accretion, erosion, and radiogenic heating. Journal of Geophysical Research, 103, 15287-15302.

Jackson, S. E., Pearson, N. J., Griffin, W. L., \& Belousova, E. A. (2004). The application of laser ablation-inductively coupled plasma mass spectrometry to in situ U-Pb zircon geochronology. Chemical Geology, 211, 47-69.

Jamieson, R. A., Beaumont, C., Fullsack, P., \& Lee, B. (1998). Barrovian regional metamorphism: where's the heat? In P. J. Treloar \& P. J. O'Brien (Eds.), What Drives Metamorphism and Metamorphic Reactions? (Vol. 138, pp. 23-51). Geological Society of London, Special Publications.

Johnson, M. R. W., \& Strachan, R. A. (2006). A discussion of possible heat sources during nappe stacking: the origin of the Barrovian metamorphism within the Caledonian thrust sheets of NW Scotland. Journal of the Geological Society of London, 163, $579-582$.

This article is protected by copyright. All rights reserved. 
Kneller, B. C., \& Aftalion, M. (1987). The isotopic and structural age of the Aberdeen Granite. Journal of the Geological Society of London, 144, 717-721.

Kohn, M. J., \& Spear, F. S. (2000). Retrograde net transfer reaction insurance for pressure-temperature estimates. Geology, 28, 1127-1130.

Kretz, R. (1983). Symbols for rock-forming minerals. American Mineralogist, 68, 277-279.

Leake, B. E., Woolley, A. R., Arps, C. E. S., Birch, W. D., Gilbert, M. C., Grice, J. D., ... Krivovichev, V. G. (1997). Nomenclature of Amphiboles: Report of the Subcommittee on Amphiboles of the International Mineralogical Association Commission on New Minerals and Mineral Names. Mineralogical Magazine, 61, $295-321$.

Leake, B. E., Woolley, A. R., Birch, W. D., Burke, E. A. J., Ferraris, G., Grice, J. D., ... Schumacher, J. C. (2004). Nomenclature of amphiboles: additions and revisions to the International Mineralogical Association's amphibole nomenclature. American Mineralogist, 89, 883-887.

Ludwig, K. R. (2003). Users manual for Isoplot 3.00. A Geochronological toolkit for Microsoft Excel ${ }^{\mathrm{TM}}$ [Computer software manual].

Lyubetskaya, T., \& Ague, J. J. (2010). Modeling metamorphism in collisional orogens intruded by magmas: II. Fluid flow and implications for Barrovian and Buchan Metamorphism, Scotland. American Journal of Science, 310, 459-491.

Maruyama, S., Liou, J. G., \& Zhang, R. (1994). Tectonic evolution of the ultrahigh-pressure (UHP) and high-pressure (HP) metamorphic belts from central China. Island Arc, 3, 112-121.

McCay, G. A., Prave, A. R., Alsop, G. I., \& Fallick, A. E. (2006). Glacial trinity: Neoproterozoic Earth history within the British-Irish Caledonides. Geology, 34 , 909-912.

McKerrow, W. S., Mac Niocaill, C., \& Dewey, J. F. (2000). The Caledonian Orogeny redefined. Journal of the Geological Society of London, 157, 1149-1154.

McLellan, E. L. (1985). Metamorphic reactions in the kyanite and sillimanite zones of the Barrovian type area. Journal of Petrology, 26, 789-818.

Morimoto, N., Fabries, J., Ferguson, A. K., Ginzburg, I. V., Ross, M., Seifert, F. A., ... Gottardi, G. (1988). Nomenclature of pyroxenes. American Mineralogist, 73, $1123-1133$.

Okay, A. I. (1989). An exotic eclogite/blueschist slice in a Barrovian-style metamorphic terrain, Alanya Nappes, Southern Turkey. Journal of Petrology, 30, 107-132.

Oliver, G. J. H. (2001). Reconstruction of the Grampian episode in Scotland: its place in the Caledonian Orogeny. Tectonophysics, 332, 23-49.

Oliver, G. J. H., Chen, F., Buchwaldt, R., \& Hegner, E. (2000). Fast

This article is protected by copyright. All rights reserved. 
tectonometamorphism and exhumation in the type area of the Barrovian and Buchan zones. Geology, 28, 459-462.

Oliver, G. J. H., Wilde, S. A., \& Wang, Y. (2008). Geochronology and geodynamics of Scottish granitoids from the late Neoproterozoic break-up of Rodinia to Paleozoic collision. Journal of the Geological Society of London, 165, 661-674.

Palin, R. M., Searle, M. P., St-Onge, M. R., Waters, D. J., Roberts, N. M. W., Horstwood, M. S. A., ... Yang, J. (2014). Monazite geochronology and petrology of kyanite- and sillimanite-grade migmatites from the northwestern flank of the eastern Himalayan syntaxis. Gondwana Research, 26, 323-347.

Palin, R. M., Weller, O. M., Waters, D. J., \& Dyck, B. (2016). Quantifying geological uncertainty in metamorphic phase equilibria modelling; a Monte Carlo assessment and implications for tectonic interpretations. Geoscience Frontiers, 7, 591-607. doi: 10.1016/j.gsf.2015.08.005

Palin, R. M., White, R. W., \& Green, E. C. R. (2016). Partial melting of metabasic rocks and the generation of tonalitic-trondhjemitic-granodioritic (TTG) crust in the Archean: constraints from phase equilibria modelling. Precambrian Research, in review.

Palin, R. M., White, R. W., Green, E. C. R., Powell, R., Diener, J. F. A., \& Holland, T. J. B. (2016). High-grade metamorphism and partial melting of basic and intermediate rocks. Journal of Metamorphic Geology, 34, 871-892.

Petersen, E. U., Essene, E. J., \& Peacor, D. R. (1982). Fluorine end-member micas and amphiboles. American Mineralogist, 67, 538-544.

Powell, R., \& Holland, T. J. B. (1988). An internally consistent dataset with uncertainties and correlations: 3. Applications to geobarometry, worked examples and a computer program. Journal of Metamorphic Geology, 6, 173-204.

Powell, R., \& Holland, T. J. B. (1994). Optimal geothermometry and geobarometry. American Mineralogist, 79, 120-133.

Powell, R., \& Holland, T. J. B. (2008). On thermobarometry. Journal of Metamorphic Geology, 26, 155-179.

Pownceby, M. I., Wall, V. J., \& O’Neill, H. S. C. (1987). Fe-Mn partitioning between garnet and ilmenite: experimental calibration and applications. Contributions to Mineralogy and Petrology, 97, 116-126.

Prave, A. R., Fallick, A. E., Thomas, C. W., \& Graham, C. M. (2009). A composite C-isotope profile for the Neoproterozoic Dalradian Supergroup of Scotland and Ireland. Journal of the Geological Society of London, 166, 845-857.

Ramsay, D. M., \& Sturt, B. A. (1979). The status of the Banff Nappe. In A. L. Harris, C. H. Holland, \& B. E. Leake (Eds.), The Caledonides of the British Isles - Reviewed 
(Vol. 8, pp. 145-151). Geological Society of London, Special Publications.

Rao, B., \& Johannes, W. (1979). Further data on the stability of staurolite + quartz and related assemblages. Neues Jahrbuch fuer Mineralogie. Monatshefte, 1, 437-447.

Read, H. H. (1955). The Banff Nappe: an interpretation of the structure of the Dalradian rocks of north-east Scotland. Proceedings of the Geologists' Association, 66, 1-29.

Renner, J., Evans, B., \& Hirth, G. (2000). On the rheologically critical melt fraction. Earth and Planetary Science Letters, 181, 585-594.

Rosenberg, C. L., \& Handy, M. R. (2005). Experimental deformation of partially melted granite revisited: implications for the continental crust. Journal of Metamorphic Geology, 23, 19-28.

Sawyer, E. W. (2001). Melt segregation in the continental crust: Distribution and movement of melt in anatectic rocks. Journal of Metamorphic Geology, 19, 291-309.

Searle, M. P., Cottle, J. M., Streule, M. J., \& Waters, D. J. (2009). Crustal melt granites and migmatites along the Himalaya: melt source, segregation, transport and granite emplacement mechanisms. Earth and Environmental Science Transactions of the Royal Society of Edinburgh, 100, 1-15.

Sláma, J., Košler, J., Condon, D. J., Crowley, J. L., Gerdes, A., Hanchar, J. M., ... Whitehouse, M. J. (2008). Plešovice zircon - a new natural reference material for $\mathrm{U}-\mathrm{Pb}$ and Hf isotopic microanalysis. Chemical Geology, 249, 1-35.

Smith, C. G., Goodman, S., \& Robertson, S. (2002). Geology of the Ballater district. Memoir of the British Geological Survey. Sheet 65E (Scotland).

Smye, A. J., Holland, T. J. B., Parrish, R. R., \& Condon, D. J. (2011). Rapid formation and exhumation of the youngest Alpine eclogites: A thermal conundrum to Barrovian metamorphism. Earth and Planetary Science Letters, 306, 193-204.

Soper, N. J., Ryan, P. D., \& Dewey, J. F. (1999). Age of the Grampian Orogeny in Scotland and Ireland. Journal of the Geological Society of London, 156, 1231-1236.

Soper, N. J., Strachan, R. A., Holdsworth, R. E., Gayer, R. A., \& O'Greiling, R. O. (1992). Sinistral transpression and the Silurian closure of Iapetus. Journal of the Geological Society of London, 149, 871-880.

Stacey, J. S., \& Kramers, J. D. (1975). Approximation of terrestrial lead isotope evolution by a two-stage model. Earth and Planetary Science Letters, 26, 207-221.

Stephenson, D., Mendum, J. R., Fettes, D. J., \& Leslie, G. (2013a). The Dalradian rocks of Scotland: an introduction. Proceedings of the Geologists' Association, 124, 3-82.

Stephenson, D., Mendum, J. R., Fettes, D. J., Smith, C. G., Gould, D., Tanner, P. W. G., \& Smith, R. A. (2013b). The Dalradian rocks of the north-east Grampian Highlands of Scotland. Proceedings of the Geologists' Association, 124, 318-392.

St-Onge, M. R., Searle, M. P., \& Wodicka, N. (2006). Trans-Hudson Orogen of North 
America and Himalaya- Karakoram-Tibetan Orogen of Asia: Structural and thermal characteristics of the lower and upper plates. Tectonics, 25, TC4006.

Stuck, T. J., \& Diener, J. F. A. (2018). Mineral equilibria constraints on opensystem melting in metamafic compositions. Journal of Metamorphic Geology, 36, 255-281.

Sturt, B. A., Ramsay, D. M., Pingle, I. R., \& Teggin, D. E. (1977). Precambrian gneisses in the Dalradian sequence of northeast Scotland. Journal of the Geological Society of London, 134, 41-44.

Stüwe, K., \& Powell, R. (1995). P-T paths from modal proportions: application to the Koralm Complex, Eastern Alps. Contributions to Mineralogy and Petrology, 119, 83-93.

Tanner, P., Thomas, C., Harris, A., Gould, D., Harte, B., Treagus, J., \& Stephenson, D. (2013). The Dalradian rocks of the Highland Border region of Scotland. Proceedings of the Geologists' Association, 124, 215-262.

Thompson, A. B., \& England, P. C. (1984). Pressure-temperature-time paths of regional metamorphism II. Their inference and interpretation using mineral assemblages in metamorphic rocks. Journal of Petrology, 25, 929-955.

Tilley, C. E. (1925). A preliminary survey of metamorphic zones in the Southern Highlands of Scotland. Quarterly Journal of the Geological Society of London, 81, 100-112.

Viete, D. R., Hermann, J., Lister, G. S., \& Stenhouse, I. (2011). The nature and origin of the Barrovian metamorphism, Scotland: diffusion length scales in garnet and inferred thermal time scales. Journal of the Geological Society of London, 168, 115-132.

Viete, D. R., Oliver, G. J. H., Fraser, G. L., Forster, M., \& Lister, G. S. (2013). Timing and heat sources for the Barrovian metamorphism, Scotland. Lithos, 177, 148-163.

Viete, D. R., Oliver, G. J. H., \& Wilde, S. A. (2014). Discussion of 'Metamorphic $P-T$ and retrograde path of high-pressure Barrovian metamorphic zones near Cairn Leuchan, Caledonian orogen, Scotland'. Geological Magazine, 4, 755-758.

Viete, D. R., Richards, S. W., Lister, G. S., Oliver, G. J. H., \& Banks, G. J. (2010). Lithospheric-scale extension during Grampian orogenesis in Scotland. In R. D. Law, R. W. H. Butler, R. E. Holdsworth, M. Krabbendam, \& R. A. Strachan (Eds.), Continental Tectonics and Mountain Building: The Legacy of Peach and Horne (Vol. 335, pp. 121-160). Geological Society of London, Special Publications.

Vigneresse, J.-L., Barbey, P., \& Cuney, M. (1996). Rheological transitions during partial melting and crystallization with application to felsic magma segregation and transfer. Journal of Petrology, 37, 1579-1600.

Vorhies, S. H., \& Ague, J. J. (2011). Pressure-temperature evolution and thermal regimes in the Barrovian zones, Scotland. Journal of the Geological Society of London, 168, $1147-1166$.

This article is protected by copyright. All rights reserved. 
Vorhies, S. H., Ague, J. J., \& Schmitt, A. K. (2013). Zircon growth and recrystallization during progressive metamorphism, Barrovian zones, Scotland. American Mineralogist, 98, 219-230.

Waters, D. J. (1988). Partial melting and the formation of granulite-facies mineral assemblages in Namaqualand, South Africa. Journal of Metamorphic Geology, 6, 387-404.

Weller, O. M., St-Onge, M. R., Searle, M. P., Rayner, N., Waters, D. J., Chung, S. L., ... Xu, X. W. (2013). Quantifying Barrovian metamorphism in the Danba Structural Culmination of eastern Tibet. Journal of Metamorphic Geology, 31, 909-935.

White, R. W., Palin, R. M., \& Green, E. C. R. (2016). Highgrade metamorphism and partial melting in Archean composite grey gneiss complexes. Journal of Metamorphic Geology, 35, 181-195.

White, R. W., \& Powell, R. (2002). Melt loss and the preservation of granulite-facies mineral assemblages. Journal of Metamorphic Geology, 20, 621-632.

White, R. W., \& Powell, R. (2010). Retrograde melt-residue interaction and the formation of near-anhydrous leucosomes in migmatites. Journal of Metamorphic Geology, 28, 579-597.

White, R. W., \& Powell, R. (2011). On the interpretation of retrograde reaction textures in granulite facies rocks. Journal of Metamorphic Geology, 29, 131-149.

White, R. W., Powell, R., \& Baldwin, J. A. (2008). Calculated phase equilibria involving chemical potentials to investigate the textural evolution of metamorphic rocks. Journal of Metamorphic Geology, 26, 181-198.

White, R. W., Powell, R., \& Clarke, G. L. (2002). The interpretation of reaction textures in Fe-rich metapelitic granulites of the Musgrave Block, central Australia: constraints from mineral equilibria calculations in the system $\mathrm{K}_{2} \mathrm{O}-\mathrm{FeO}-\mathrm{MgO}-\mathrm{Al}_{2} \mathrm{O}_{3}-\mathrm{SiO}_{2}-\mathrm{H}_{2} \mathrm{O}-\mathrm{TiO}_{2}-\mathrm{Fe}_{2} \mathrm{O}_{3}$. Journal of Metamorphic Geology, 20, 41-55.

White, R. W., Powell, R., \& Halpin, J. A. (2004). Spatially-focussed melt formation in aluminous metapelites from Broken Hill, Australia. Journal of Metamorphic Geology, 22, 825-845.

White, R. W., Powell, R., Holland, T. J. B., Johnson, T. E., \& Green, E. C. R. (2014a). New mineral activity-composition relations for thermodynamic calculations in metapelitic systems. Journal of Metamorphic Geology, 32, 261-286.

White, R. W., Powell, R., Holland, T. J. B., \& Worley, B. A. (2000). The effect of $\mathrm{TiO}_{2}$ and $\mathrm{Fe}_{2} \mathrm{O}_{3}$ on metapelitic assemblages at greenschist and amphibolite facies conditions: mineral equilibria calculations in the system $\mathrm{K}_{2} \mathrm{O}-\mathrm{FeO}-\mathrm{MgO}-\mathrm{Al}_{2} \mathrm{O}_{3}-\mathrm{SiO}_{2}-\mathrm{H}_{2} \mathrm{O}-\mathrm{TiO}_{2}-\mathrm{Fe}_{2} \mathrm{O}_{3}$. Journal of Metamorphic Geology, 
$18,497-511$.

White, R. W., Powell, R., \& Johnson, T. E. (2014b). The effect of Mn on mineral stability in metapelites revisited: new $a-x$ relations for manganese-bearing minerals. Journal of Metamorphic Geology, 32, 809-828.

Wiedenbeck, M., Allé, P., Corfu, F., Griffin, W. L., Meier, M., Oberli, F., ... Spiegel, W. (1995). Three natural zircon standards for $\mathrm{U}-\mathrm{Th}-\mathrm{Pb}, \mathrm{Lu}-\mathrm{Hf}$, trace element and REE analyses. Geostandards Newsletter, 19, 1-23.

Wing, B., \& Ferry, J. M. (2002). Three-dimensional geometry of metamorphic fluid flow during Barrovian regional metamorphism from an inversion of combined petrologic and stable isotopic data. Geology, 30, 639-642.

Ziberna, L., Green, E. C. R., \& Blundy, J. D. (2017). Multiple-reaction geobarometry for olivine-bearing igneous rocks. American Mineralogist, 102, 2349-2366.

\section{SUPPORTING INFORMATION}

Additional Supporting Information may be found online in the supporting information tab for this article.

Table S1. Results of LA-ICP-MS zircon U-Pb analysis.

\section{Table captions}

Table 1: Representative mineral compositions (wt.\% oxide and cations per formula unit) from samples CL01 (semipelitic migmatite), CL02 and CL03 (mafic migmatites), and CL10 (garnetite vein-bearing mafic migmatite). Proportions of $\mathrm{Fe}_{2} \mathrm{O}_{3}$ and $\mathrm{Fe}^{3+}$ were calculated using AX (Holland, 2009). Phase abbreviations follow the guidelines of Kretz (1983).

Table 2: Bulk-rock major-element oxide (weight \% oxide) and trace element $(\mu \mathrm{g} / \mathrm{g})$ compositions of Cairn Leuchan samples CL01, CL02, and CL03. Individual $\mathrm{Fe}_{2} \mathrm{O}_{3}$ and $\mathrm{FeO}$ contents were determined via titration. $\mathrm{LOI}=$ loss on ignition.

Table 3: Bulk-rock compositions used for phase diagram construction (mole $\%$ oxide). FeO ${ }^{\text {tot }}$ is total iron expressed as $\mathrm{FeO}$. $\mathrm{O}$ is oxygen, which combines with $\mathrm{FeO}$ via the equation $2 \mathrm{FeO}$ $+\mathrm{O}=\mathrm{Fe}_{2} \mathrm{O}_{3}$; hence, bulk $\mathrm{O}$ is identically equal to bulk $\mathrm{Fe}_{2} \mathrm{O}_{3}$, while true bulk $\mathrm{FeO}$ is given by $\mathrm{FeO}^{\text {tot }}-2 \times \mathrm{O}$. Bulk-rock $X_{\mathrm{Mg}}=\mathrm{MgO} /\left(\mathrm{MgO} / \mathrm{FeO}^{\text {tot }}\right)$, and $X_{\mathrm{Fe}^{3+}}=(2 \times \mathrm{O}) / \mathrm{FeO}^{\text {tot }}$. 
Table 4: Results of avP calculations for determination of pressures of equilibration in samples CL02 and CL03. Pressures were calculated every $50{ }^{\circ} \mathrm{C}$ across the temperature range of interest, and are associated with individual significant fit values, which were below the cutoffs for $95 \%$ confidence in each case (1.49 for CL02 and 1.45 for CL03).

\section{Figure captions}

Figure 1: (a) Regional tectonic map of the northern British Isles, and (b) metamorphic map of the entire Grampian Terrane and Glen Muick region, modified from Stephenson et al. (2013a) and Vorhies et al. (2013). Map co-ordinates are those of the United Kingdom Ordnance Survey National Grid. Abbreviations for tectonic features and localities are as follows: $\mathrm{GG}=$ Glen Girnock, $\mathrm{MT}=$ Moine Thrust, GGF = Great Glen Fault, HBF = Highland Boundary Fault, SUF = Southern Uplands Fault, ISZ = Iapetus Suture Zone.

Figure 2: Outcrop map showing sample localities and field photographs from the hill of Cairn Leuchan, Glen Muick. Penknife and pen are both $\sim 8 \mathrm{~cm}$ long. (a) Leucosome-matrix associations in a typical mafic migmatite, (b) strongly folded semipelitic migmatite with up to $\sim 30 \%$ leucosome, (c) garnet-dominated ('garnetite') veins in mafic migmatites containing additional quartz, plagioclase, amphibole, and diopside, (d) diopside-rich leucosome in mafic migmatite; (e) garnetite vein showing a continuous lateral transition into a garnet-free (or garnet-poor) leucosome, (f) disrupted matrix folia associated with boudinage and localised melt migration.

Figure 3: Plane-polarised light photomicrographs of petrological features in Cairn Leuchan migmatites. Scale bar is $1 \mathrm{~cm}$. (a) Semipelitic migmatite sample CL01 with well-defined leucosome (leuco) and matrix domains. The former are largely characterised by quartz, plagioclase, K-feldspar, and minor sillimanite, whereas the latter mostly contain quartz plagioclase, biotite, garnet, sillimanite, and rutile. (b) mafic migmatite sample CL02 containing tonalitic quartz-plagioclase leucosomes and an amphibole-garnet-diopside-ilmenite-quartz matrix. Peritectic diopside occurs within leucosome domains. (c) Metabasic sample CL03 containing large diopside porphyroblasts in matrix domains. (d) Mafic migmatite sample CL10 showing a sharp transition from garnet-rich leucosome domains ('garnetite vein') to relatively garnet-poor amphibole-, diopside-, ilmenite-, quartz-, and plagioclase-bearing matrix.

This article is protected by copyright. All rights reserved. 
Figure 4: Compositions of garnet and biotite in Cairn Leuchan migmatites. (a) Representative Fe (blue), Mg (brown), Ca (orange), and Mn (green) cation mole fractions for garnet from matrix domains in samples CL01 (dashed box), CL02, CL03, and CL10, and from garnetite veins from sample CL10. Some grains analysed from garnetite veins in CL10 had Mn-enriched cores (dashed ellipse; cf. Fig. 5). (b) Compositions of biotite from semipelitic migmatite CL01 plotted on the $X_{\mathrm{Mg}}$ vs Ti cpfu (for 22 oxygens) diagram of Henry et al. (2005). All data points lie between isotherms delimiting $T=690-750{ }^{\circ} \mathrm{C}$.

Figure 5: X-ray maps showing the relative concentrations of $\mathrm{Ca}$ and $\mathrm{Mn}$ in different grains within sample CL10 garnetite vein. Scale bar is $1 \mathrm{~mm}$. BSE = back-scattered electron.

Figure 6: $P-T$ pseudosections calculated for mafic migmatite samples (a) CL02 and (b) CL03. Assemblage fields marked with bold text constrain the likely $P-T$ conditions at which each sample preserved its final mineral assemblage upon crossing the solidus. Red, dashed ellipse represents the peak $P-T$ conditions for Cairn Leuchan mafic migmatites reported by Aoki et al. (2014a). Grey band shows the results of avP calculations with a 1 S.D. uncertainty envelope. Numbered fields for CL02 are as follows (+Pl, Aug): 1 - L Grt Hbl Bt Kfs Rt Qtz (-Pl), 2- Grt Hbl Kfs Rt Qtz (-Pl), 3 - Grt Hbl Bt Ilm Qtz, 4 - Grt Opx Hbl Bt Kfs Ilm Qtz, 5 - Grt Opx Hbl Kfs Ilm Qtz, 6 - Opx Hbl Bt Kfs Ilm Qtz, 7 - L Hbl Bt Opx Ilm Mag, 8 - L Grt Hbl Opx Ilm Qtz, 9 - L Grt Hbl Ilm Rt Qtz, 10 - L Grt Hbl Rt Qtz, 11 L Grt Ilm Rt. Numbered fields for CL03 are as follows (+Pl, Aug, Qtz): 12 - Hbl Opx Kfs Mag Ilm, 13 - Hbl Opx Mag Ilm, 14 - L Grt Hbl Opx Ilm.

Figure 7: Calculated pseudosection showing the effects on phase equilibria for sample CL03 at peak metamorphism based on re-integrating lost melt. At 9 kbar, phase assemblages as a function of temperature are shown for the observed, melt-depleted CL03 bulk composition on the left-hand side of the pseudosection ( $0 \%$ melt re-integrated). At the same pressure, phase assemblages that would be in equilibrium with up to $30 \%$ melt re-integrated to the bulk-rock composition are shown along the $x$-axis. 
Figure 8: Pseudosections calculated for semipelitic migmatite sample CL01. (a) $P-T$ pseudosection. The assemblage fields L-Grt-Bt-Pl-Qtz-Ilm-Sill $\pm \mathrm{H}_{2} \mathrm{O}$ (bold text) constrains the likely $P-T$ conditions over which the sample cooled and preserved its mineral assemblage upon crossing the solidus during exhumation. Red, dashed ellipse represents the peak $P-$ $T$ conditions for Cairn Leuchan mafic migmatites reported by Aoki et al. (2014a). Blue, dashed box represents the peak conditions reached by other sillimanite-grade Barrow zone metapelites that outcrop outside of the Glen Muick area (Ague et al., 2001; Baker, 1985; Vorhies \& Ague, 2011). Numbered fields are as follows (+Pl, Qtz): 1 - Grt Bt Ms Ilm Rt $\mathrm{H}_{2} \mathrm{O}, 2$ - Grt Bt Ms Ilm Ky $\mathrm{H}_{2} \mathrm{O}, 3$ - Grt Bt Ilm Sill $\mathrm{H}_{2} \mathrm{O}, 4$ - Crd Bt Ilm Sill $\mathrm{H}_{2} \mathrm{O}$, 5 - L Crd Bt Ilm Sill, 6 - L Grt Kfs Bt Ilm Ky, 7 - L Grt Crd Opx Ilm. (b) $T-M_{\mathrm{H}_{2} \mathrm{O}}$ pseudosection. Brown dashed lines represent the calculated molar proportion of biotite at suprasolidus conditions.

Figure 9: Tera-Wasserburg plots showing the results of U-Pb zircon geochronology for samples CL01, CL02, and CL03. Dashed lines represent regressions from a ${ }^{207} \mathrm{~Pb} /{ }^{206} \mathrm{~Pb}$ ratio of $0.83 \pm 0.02$. All ages represent calculated intersections with Concordia. Red-filled ellipses represent those considered to form major populations in each sample, as discussed in the main text. (a) CL01, (b) CL02, and (c) CL03. (d) Typical zircon morphologies and representative single spot analysis ages for samples (d) CL01, (e) CL02, and (f) CL03.

Figure 10: Schematic interpretation for the formation of Cairn Leuchan garnetite veins. An idealised model for mineral textural development is shown during prograde metamorphism through subsolidus ( $\mathrm{a}-\mathrm{b})$ and suprasolidus ( $\mathrm{c}-\mathrm{e}$ ) conditions. Dashed lines in (a) and (b) represent theoretical Mn-depleted regions that form around newly nucleated garnet grains. Panels (f) and (g) show simplified petrological tracings of garnetite-leucosome occurrences at Cairn Leuchan. Scale bar on each is $1 \mathrm{~cm}$. In all cases, the matrix represents an amphiboleand plagioclase-dominated aggregate, with or without quartz, ilmenite, or melt. 


\begin{tabular}{|c|c|c|c|c|c|c|c|c|c|c|c|c|c|c|c|c|c|c|}
\hline $\mathrm{MgO}$ & 10.77 & 14.45 & 7.56 & 0.13 & 0.00 & 0.01 & 0.01 & 9.83 & 11.61 & 10.14 & 4.46 & 0.29 & 0.00 & 0.03 & & & & \\
\hline $\mathrm{CaO}$ & 0.02 & 0.00 & 1.81 & 0.00 & 7.07 & 7.33 & 0.30 & 10.96 & 20.77 & 21.64 & 7.29 & 0.00 & 8.07 & 4.96 & & & & \\
\hline $\mathrm{Na}_{2} \mathrm{O}$ & 0.26 & 0.14 & 0.00 & 0.03 & 7.43 & 6.95 & 0.03 & 1.72 & 0.38 & 0.76 & 0.00 & 0.00 & 6.68 & 8.09 & & & & \\
\hline $\mathrm{K}_{2} \mathrm{O}$ & 9.06 & 9.39 & 0.00 & 0.00 & 0.19 & 0.24 & 16.21 & 1.04 & 0.00 & 0.01 & 0.01 & 0.00 & 0.14 & 0.47 & & & & \\
\hline Total & 94.14 & 93.63 & 100.55 & 98.32 & 98.48 & 97.97 & 100.10 & 98.21 & 98.68 & 99.00 & 99.29 & 98.40 & 98.06 & 98.09 & & & & \\
\hline $\mathrm{Si}$ & 2.76 & 2.77 & 3.00 & 0.00 & 2.69 & 2.67 & 2.97 & 6.47 & 1.97 & 1.94 & 2.99 & 0.00 & 2.63 & 2.75 & & & & \\
\hline$T_{i}$ & 0.25 & 0.15 & 0.00 & 1.00 & 0.00 & 0.00 & 0.00 & 0.27 & 0.01 & 0.01 & 0.00 & 1.00 & 0.00 & 0.00 & & & & \\
\hline $\mathrm{Al}$ & 1.47 & 1.57 & 1.98 & 0.00 & 1.31 & 1.33 & 1.02 & 2.01 & 0.10 & 0.12 & 1.97 & 0.00 & 1.36 & 1.25 & & & & \\
\hline $\mathrm{Fe} 3+$ & 0.00 & 0.00 & 0.02 & 0.00 & 0.00 & 0.00 & 0.01 & 0.21 & 0.00 & 0.05 & 0.04 & 0.01 & 0.00 & 0.00 & & & & \\
\hline $\mathrm{Fe} 2+$ & 1.07 & 0.74 & 1.91 & 0.96 & 0.00 & 0.00 & 0.00 & 1.90 & 0.37 & 0.36 & 1.74 & 0.97 & 0.00 & 0.00 & & & & \\
\hline $\mathrm{Mn}$ & 0.01 & 0.00 & 0.07 & 0.03 & 0.00 & 0.00 & 0.00 & 0.03 & 0.01 & 0.00 & 0.11 & 0.02 & 0.00 & 0.00 & & & & \\
\hline $\mathrm{Mg}$ & 1.22 & 1.60 & 0.87 & 0.01 & 0.00 & 0.00 & 0.00 & 2.18 & 0.66 & 0.58 & 0.53 & 0.00 & 0.00 & 0.00 & & & & \\
\hline $\mathrm{Ca}$ & 0.00 & 0.00 & 0.15 & 0.00 & 0.34 & 0.36 & 0.02 & 1.75 & 0.84 & 0.88 & 0.62 & 0.00 & 0.39 & 0.25 & & & & \\
\hline $\mathrm{Na}$ & 0.04 & 0.02 & 0.00 & 0.00 & 0.65 & 0.63 & 0.00 & 0.50 & 0.04 & 0.06 & 0.00 & 0.00 & 0.61 & 0.72 & & & & \\
\hline $\mathrm{K}$ & 0.88 & 0.89 & 0.00 & 0.00 & 0.01 & 0.01 & 0.98 & 0.20 & 0.00 & 0.00 & 0.00 & 0.00 & 0.01 & 0.03 & & & & \\
\hline Sum & 7.70 & 7.74 & 8.00 & 2.00 & 5.00 & 5.00 & 5.00 & 15.52 & 4.00 & 4.00 & 8.00 & 2.00 & 5.00 & 5.00 & & & & \\
\hline Oxygen & 11 & 11 & 12 & 3 & 8 & 8 & 8 & 23 & 6 & 6 & 12 & 3 & 8 & 8 & & & & \\
\hline Sample & CL03 & CL03 & CL03 & CL03 & CL03 & CL03 & CL03 & CL10 & CL10 & CL10 & CL10 & CL10 & CL10 & CL10 & $\mathrm{CL} 10$ & CL10 & CL10 & \\
\hline Mineral & Amph & $\mathrm{Di}$ & $\mathrm{Di}$ & Grt & $\| \mathrm{m}$ & $\mathrm{PI}$ & $\mathrm{PI}$ & Amph & Amph & Cpx & Cpx & Grt & Grt & Grt & $\| \mathrm{m}$ & $\mathrm{PI}$ & $\mathrm{PI}$ & \\
\hline Location & Matrix & Matrix & Leuco & Matrix & Matrix & Matrix & Leuco & Matrix & Garnetite & Garnetite & Matrix & Matrix & Garnetite & High-Mn & Matrix & Matrix & Garnetite & \\
\hline & & p'blast & p'blast & p'blast & & & & & vein & vein & & p'blast & vein & core & & & vein & \\
\hline $\mathrm{SiO}_{2}$ & 41.03 & 50.70 & 51.12 & 37.87 & 0.10 & 56.14 & 57.92 & 42.09 & 41.20 & 50.19 & 51.35 & 37.74 & 38.06 & 35.93 & 0.02 & 57.52 & 56.03 & \\
\hline $\mathrm{TiO}_{2}$ & 2.14 & 0.30 & 0.17 & 0.13 & 51.65 & 0.02 & 0.00 & 1.84 & 1.78 & 0.23 & 0.37 & 0.00 & 0.09 & 0.06 & 51.46 & 0.00 & 0.00 & \\
\hline $\mathrm{A}_{12} \mathrm{O}_{3}$ & 12.51 & 2.93 & 2.61 & 20.77 & 0.01 & 26.44 & 25.04 & 10.99 & 11.66 & 2.68 & 1.61 & 20.50 & 20.87 & 20.83 & 0.02 & 25.39 & 26.34 & \\
\hline $\mathrm{Fe}_{2} \mathrm{O}_{3}$ & 1.21 & 0.00 & 0.08 & 0.55 & 0.94 & 0.10 & 0.06 & 1.12 & 1.76 & 1.59 & 0.83 & 1.52 & 1.13 & 0.87 & 1.97 & 0.06 & 0.02 & \\
\hline $\mathrm{FeO}$ & 16.95 & 13.45 & 12.30 & 28.67 & 45.71 & 0.00 & 0.00 & 17.34 & 17.99 & 12.29 & 11.72 & 26.90 & 24.93 & 25.83 & 41.32 & 0.00 & 0.00 & \\
\hline $\mathrm{MnO}$ & 0.08 & 0.16 & 0.16 & 1.05 & 0.39 & 0.02 & 0.01 & 0.14 & 0.35 & 0.32 & 0.28 & 1.71 & 1.50 & 3.96 & 4.81 & 0.00 & 0.00 & \\
\hline $\mathrm{MgO}$ & 8.02 & 9.83 & 10.28 & 3.07 & 0.26 & 0.01 & 0.00 & 8.49 & 7.36 & 10.37 & 10.91 & 3.39 & 3.22 & 2.10 & 0.06 & 0.00 & 0.00 & \\
\hline $\mathrm{CaO}$ & 11.07 & 20.85 & 21.23 & 7.87 & 0.00 & 9.59 & 8.28 & 11.44 & 11.10 & 20.83 & 22.31 & 7.88 & 10.18 & 9.45 & 0.00 & 8.22 & 8.74 & \\
\hline $\mathrm{Na}_{2} \mathrm{O}$ & 1.70 & 0.65 & 0.71 & 0.01 & 0.00 & 5.97 & 6.62 & 1.12 & 1.04 & 0.50 & 0.36 & 0.07 & 0.07 & 0.00 & 0.00 & 6.66 & 6.53 & \\
\hline $\mathrm{K}_{2} \mathrm{O}$ & 0.89 & 0.01 & 0.00 & 0.02 & 0.00 & 0.16 & 0.12 & 1.42 & 1.44 & 0.04 & 0.01 & 0.01 & 0.01 & 0.03 & 0.00 & 0.11 & 0.13 & \\
\hline Total & 95.60 & 98.88 & 98.66 & 100.01 & 99.06 & 98.45 & 98.05 & 95.99 & 95.68 & 99.04 & 99.75 & 99.72 & 100.06 & 99.06 & 99.66 & 97.96 & 97.79 & \\
\hline $\mathrm{Si}$ & 6.33 & 1.95 & 1.96 & 3.01 & 0.00 & 2.56 & 2.64 & 6.49 & 6.41 & 1.93 & 1.95 & 3.00 & 3.00 & 3.00 & 0.00 & 2.62 & 2.57 & \\
\hline$T_{i}$ & 0.25 & 0.01 & 0.01 & 0.01 & 0.99 & 0.00 & 0.00 & 0.21 & 0.21 & 0.01 & 0.01 & 0.00 & 0.01 & 0.00 & 0.98 & 0.00 & 0.00 & \\
\hline Al & 2.28 & 0.13 & 0.12 & 1.94 & 0.00 & 1.42 & 1.35 & 2.00 & 2.14 & 0.12 & 0.07 & 1.92 & 1.94 & 1.94 & 0.00 & 1.37 & 1.42 & \\
\hline $\mathrm{Fe}^{3+}$ & 0.14 & 0.00 & 0.00 & 0.03 & 0.02 & 0.00 & 0.00 & 0.13 & 0.21 & 0.05 & 0.02 & 0.09 & 0.07 & 0.04 & 0.04 & 0.00 & 0.00 & \\
\hline $\mathrm{Fe}^{2+}$ & 2.19 & 0.43 & 0.40 & 1.90 & 0.97 & 0.00 & 0.00 & 2.24 & 2.34 & 0.40 & 0.37 & 1.79 & 1.64 & 1.55 & 0.88 & 0.00 & 0.00 & \\
\hline $\mathrm{Mn}$ & 0.01 & 0.01 & 0.01 & 0.07 & 0.01 & 0.00 & 0.00 & 0.02 & 0.05 & 0.01 & 0.01 & 0.12 & 0.10 & 0.27 & 0.10 & 0.00 & 0.00 & \\
\hline $\mathrm{Mg}$ & 1.84 & 0.56 & 0.59 & 0.36 & 0.01 & 0.00 & 0.00 & 1.95 & 1.71 & 0.59 & 0.62 & 0.40 & 0.37 & 0.25 & 0.00 & 0.00 & 0.00 & \\
\hline $\mathrm{Ca}$ & 1.83 & 0.86 & 0.87 & 0.67 & 0.00 & 0.47 & 0.41 & 1.89 & 1.85 & 0.85 & 0.92 & 0.67 & 0.86 & 0.95 & 0.00 & 0.40 & 0.42 & \\
\hline $\mathrm{Na}$ & 0.51 & 0.05 & 0.05 & 0.00 & 0.00 & 0.53 & 0.60 & 0.34 & 0.31 & 0.04 & 0.03 & 0.01 & 0.01 & 0.00 & 0.00 & 0.60 & 0.58 & \\
\hline $\mathrm{K}$ & 0.18 & 0.00 & 0.00 & 0.00 & 0.00 & 0.01 & 0.01 & 0.28 & 0.29 & 0.00 & 0.00 & 0.00 & 0.00 & 0.00 & 0.00 & 0.01 & 0.01 & \\
\hline Sum & 15.55 & 4.00 & 4.00 & 8.00 & 2.00 & 5.00 & 5.00 & 15.55 & 15.52 & 4.00 & 4.00 & 8.00 & 8.00 & 8.00 & 2.00 & 5.00 & 5.00 & \\
\hline Oxygen & 23 & 6 & 6 & 12 & 3 & 8 & 8 & 23 & 23 & 6 & 6 & 12 & 12 & 12 & 3 & 8 & 8 & \\
\hline & & & & & & & & & & & & & & & & & & \\
\hline & & & & & & & & & & & & & & & & & & \\
\hline
\end{tabular}

This article is protected by copyright. All rights reserved. 


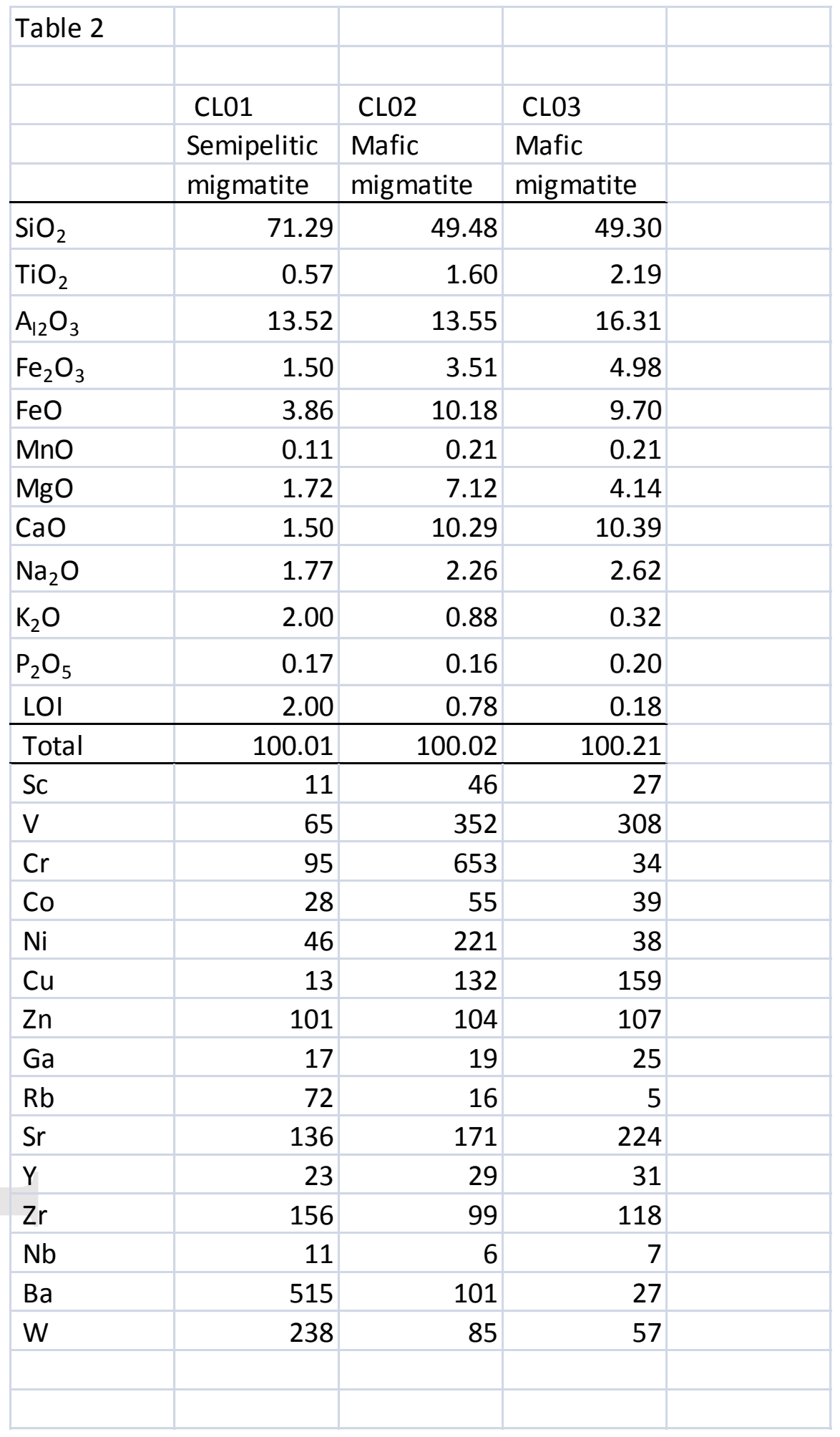

This article is protected by copyright. All rights reserved. 


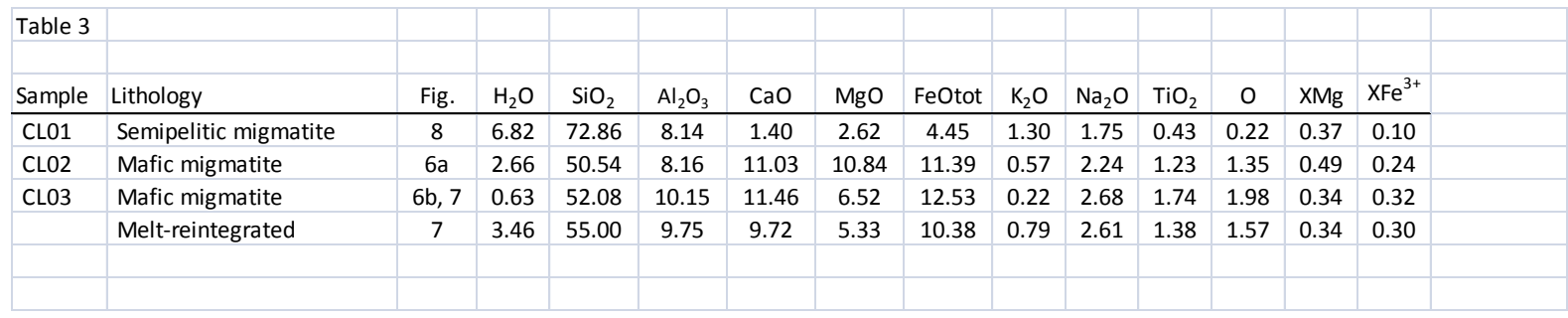

\begin{tabular}{|l|r|r|r|r|r|r|}
\hline Table 4 & & & & & & \\
\hline CL02 & & & & & & \\
\hline Temperature ( ${ }^{\circ} \mathrm{C}$ ) & 700 & 750 & 800 & 850 & 900 & 950 \\
\hline Pressure (kbar) & 7.6 & 8.1 & 8.6 & 9.2 & 9.7 & 10.3 \\
\hline 1 s.d. (kbar) & 1.09 & 1.13 & 1.19 & 1.25 & 1.3 & 1.36 \\
\hline Significant fit & 1 & 0.7 & 0.5 & 0.4 & 0.3 & 0.4 \\
\hline CL03 & & & & & & \\
\hline Temperature $\left({ }^{\circ} \mathrm{C}\right)$ & 700 & 750 & 800 & 850 & 900 & 950 \\
\hline Pressure (kbar) & 7.4 & 8 & 8.5 & 9.1 & 9.7 & 10.3 \\
\hline 1 s.d. (kbar) & 1.02 & 1.07 & 1.14 & 1.19 & 1.25 & 1.3 \\
\hline Significant fit & 1 & 0.8 & 0.7 & 0.7 & 0.8 & 0.9 \\
\hline & & & & & & \\
\hline
\end{tabular}

This article is protected by copyright. All rights reserved. 

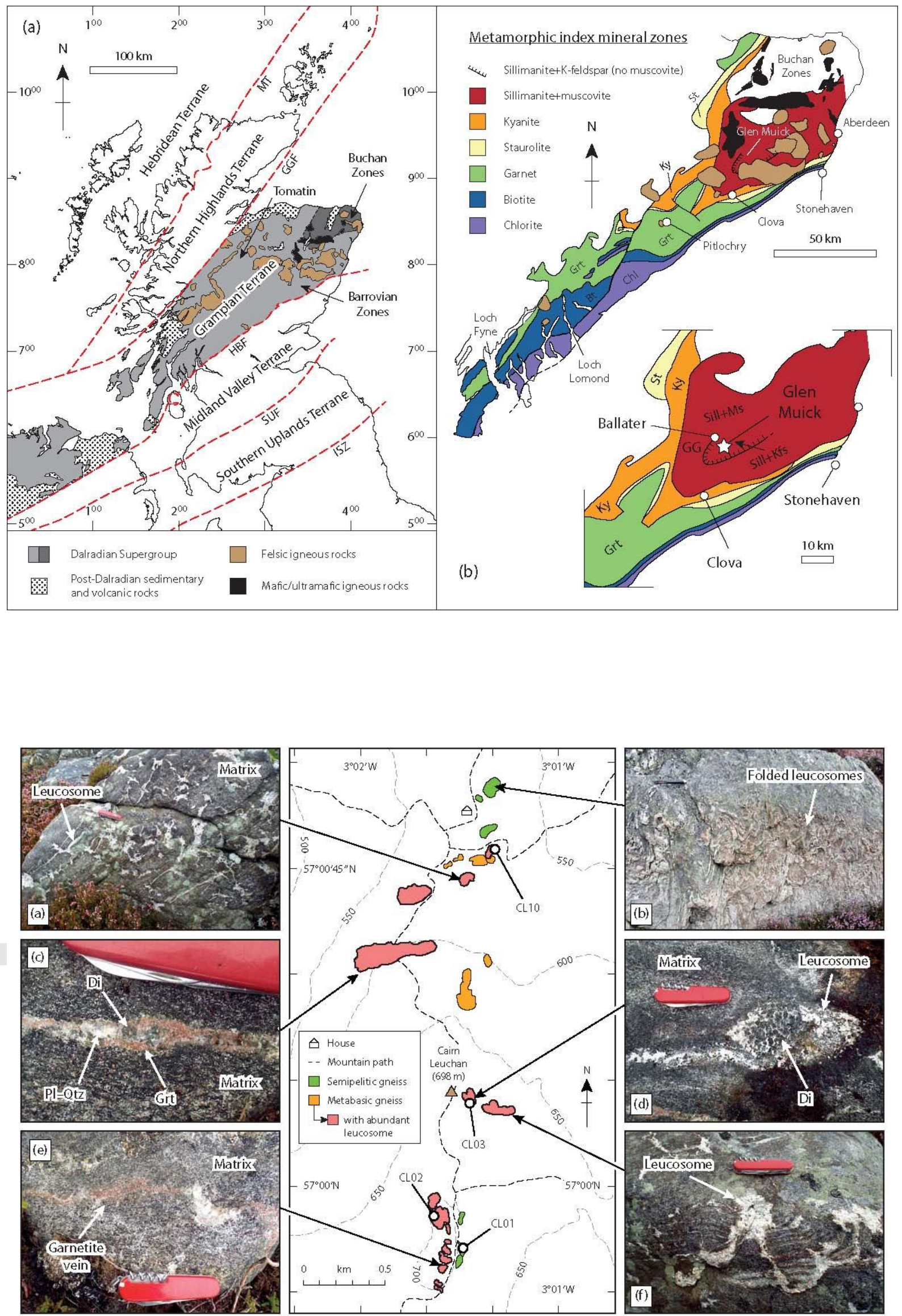

This article is protected by copyright. All rights reserved. 

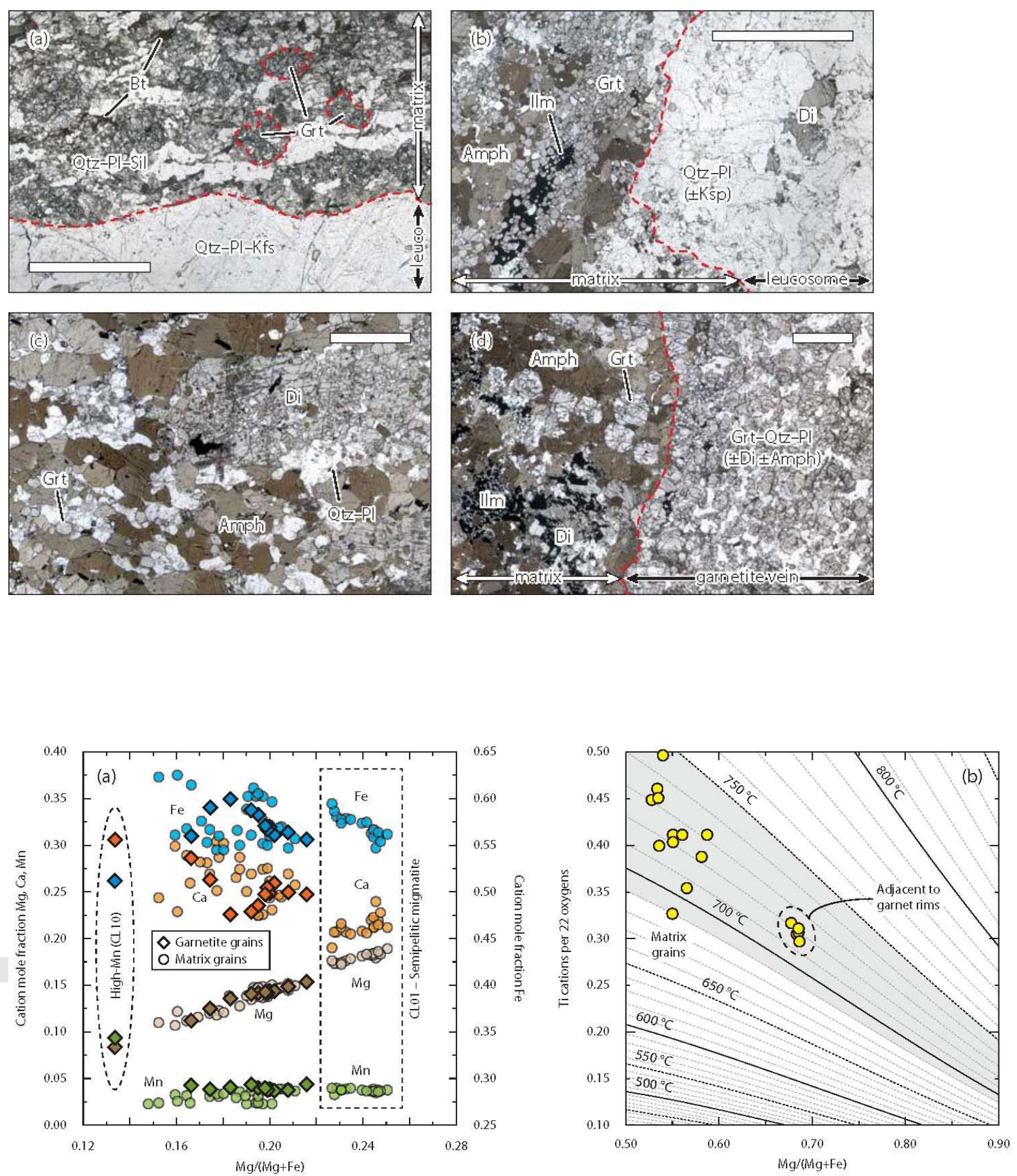

This article is protected by copyright. All rights reserved. 

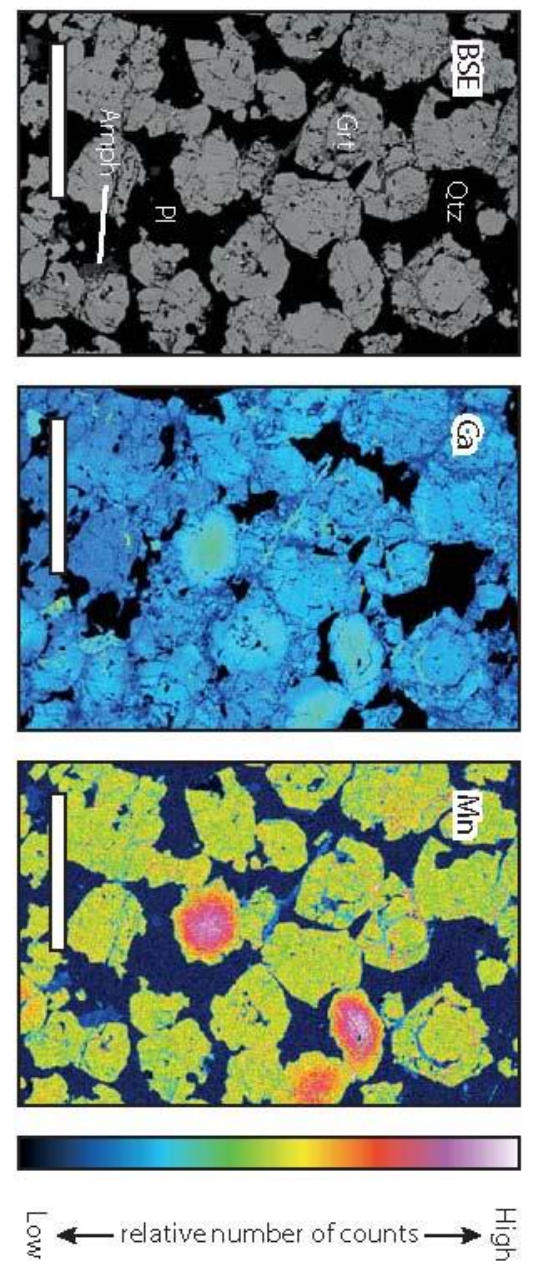

This article is protected by copyright. All rights reserved. 

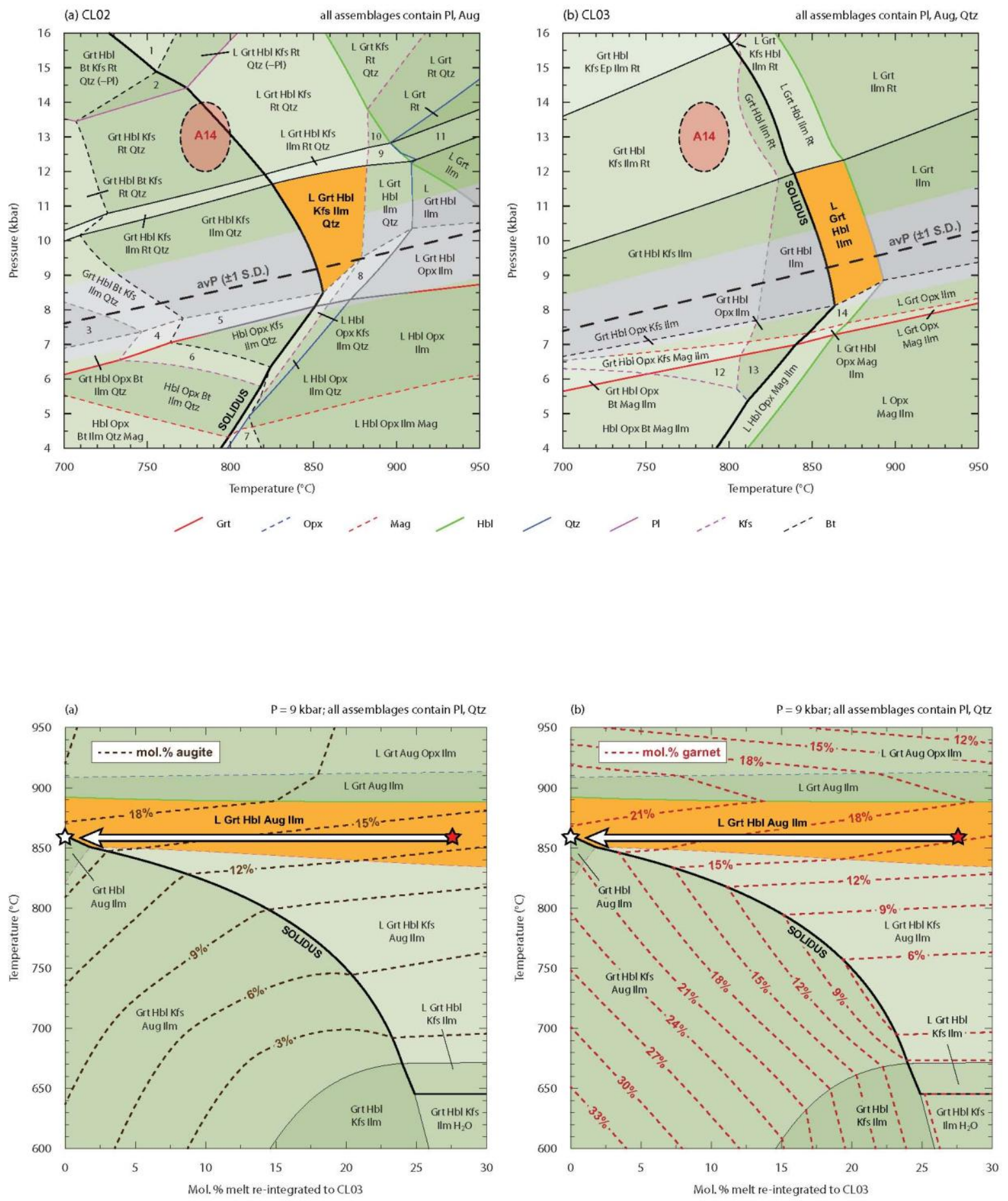

This article is protected by copyright. All rights reserved. 

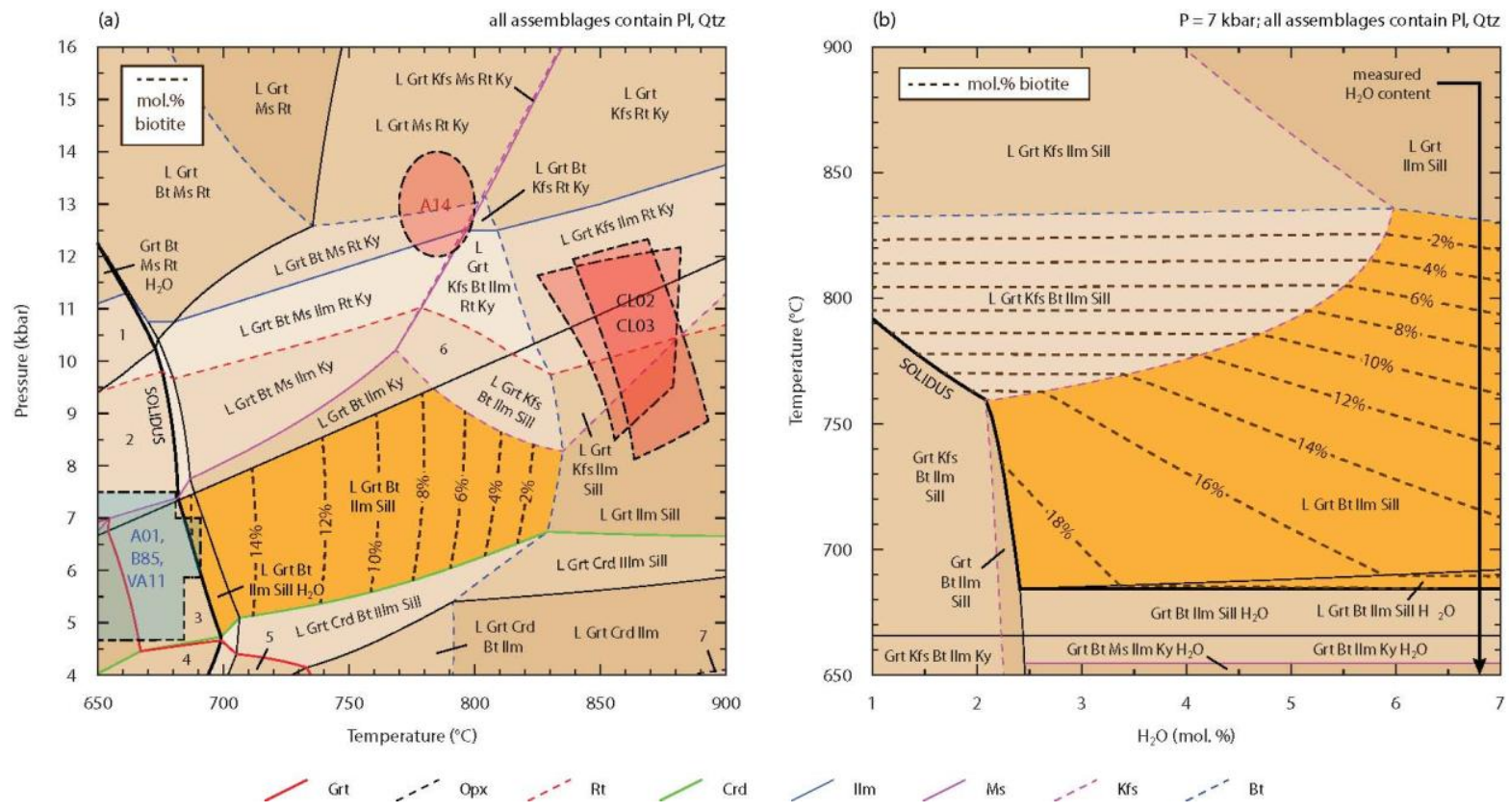

This article is protected by copyright. All rights reserved. 

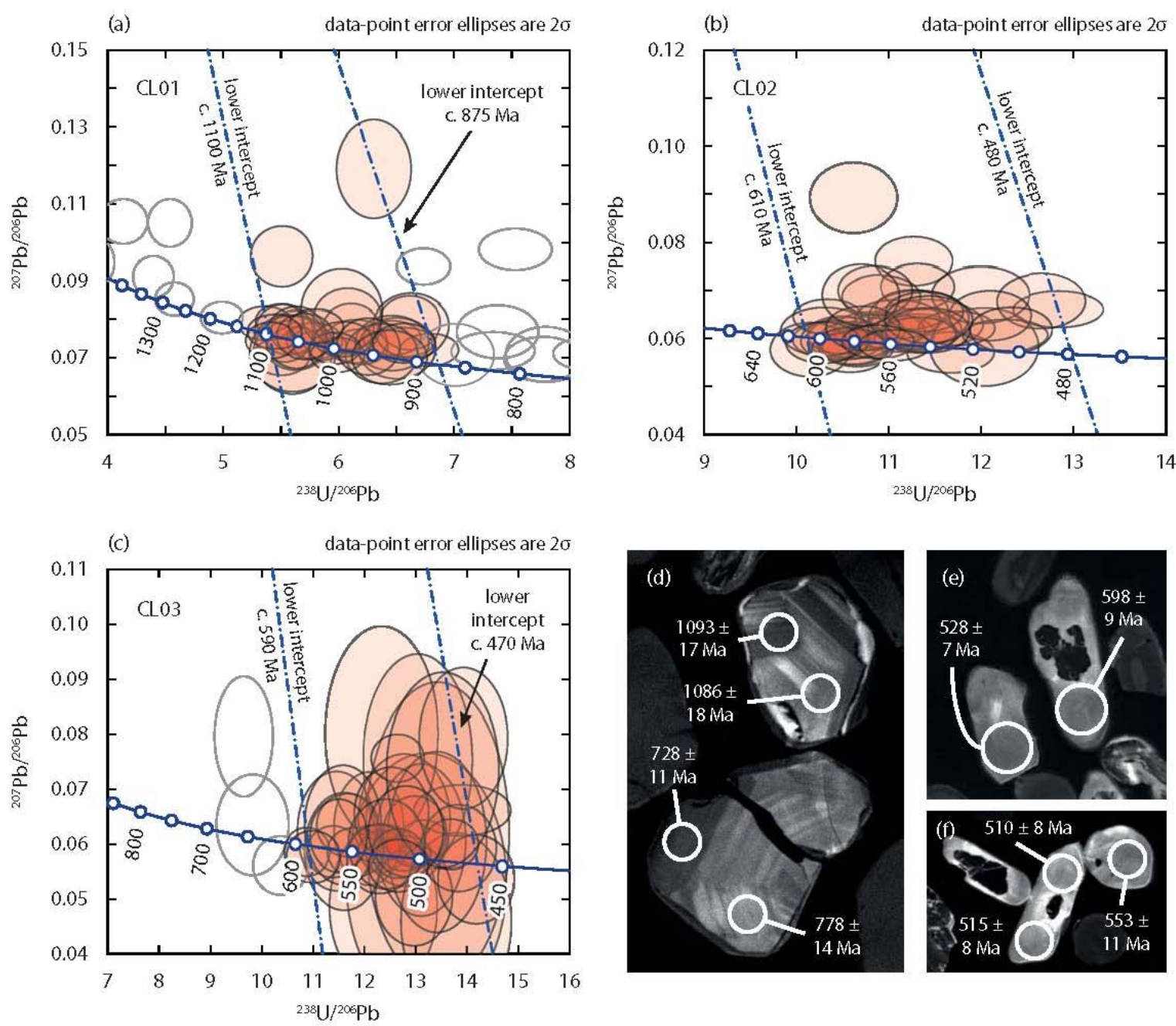

This article is protected by copyright. All rights reserved. 

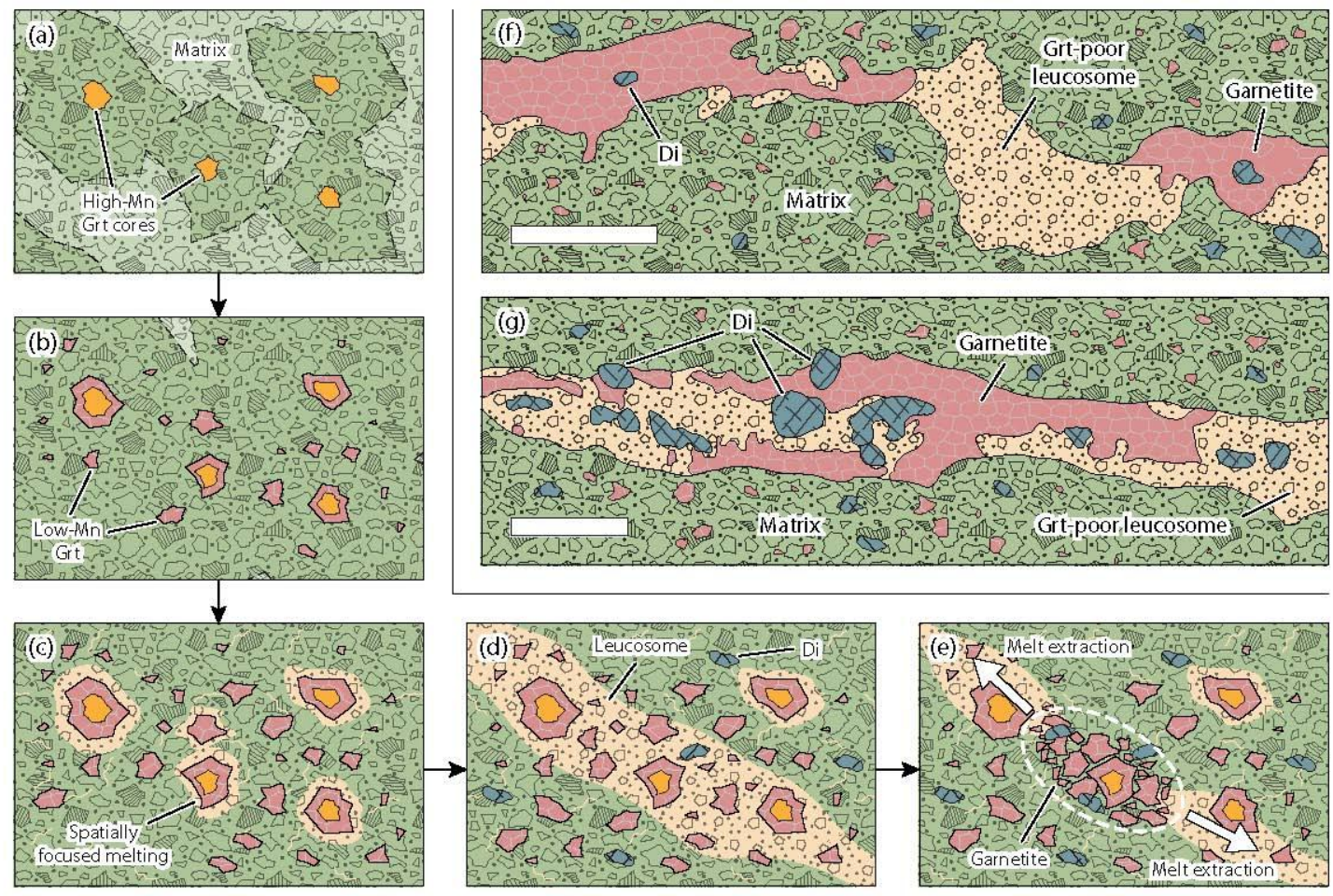

This article is protected by copyright. All rights reserved. 